http://jmscr.igmpublication.org/home/ ISSN (e)-2347-176x ISSN (p) 2455-0450 crossref DOI: https://dx.doi.org/10.18535/jmscr/v9i8.24

\title{
Efficacy Outcomes on morbidity and mortality of Intravenous Bolus Artesunate Therapy among Rapid Antigen Test and RT-PCR Negative Hospitalized Moderate to Severe Clinically Proven COVID-19 Patients: A Breakthrough large case series
}

\author{
Authors \\ Pradhan B, Kullu BK, Thakur AK, Mohapatra MK, Akhil NV, \\ Panigrahi DK, Murmu M, Majhi CD, Nanda BC.
}

\begin{abstract}
COVID-19 infection is not restricted to respiratory system and is a multisystem inflammatory disease, involving complex interplay of immunological, inflammatory, coagulation cascades, age and co-morbidities manifested by elevated inflammatory markers, coagulation disorders and immunological dysfunction with variable clinical manifestations. The diagnostic gold standard RT-PCR test has frequent false negative results. Diagnosis of clinical COVID-19 infection among highly suspected RT-PCR negative moderate to severe cases were done by measurement of panel of diagnostic criteria from baseline routine blood test, inflammatory blood biomarkers, coagulation dysfunction and imaging studies. Further confirmation of diagnosis was made by testing of COVID-19 specific antibodies at appropriate follow up time. Artesunate have antiviral effects against SARS-CoV-2 in-vitro studies. Empirical IV bolus Artesunate therapy of clinical COVID-19 associate with faster resolution of symptoms and appears to be very effective with excellent safety profile; prevents disease progression, thereby reduces morbidity and mortality among clinically diagnosed moderate to severe COVID-19 patients.

Keywords: COVID-19, IV Artesunate, Inflammatory blood biomarkers, diagnosis, COVID-19 antibodies.
\end{abstract}

\section{Introduction}

COVID-19 is not a localized respiratory infection, but a multisystem disease caused by a diffuse systemic process involving a complex interplay of immunological, inflammatory and coagulation cascades. Genetic and acquired differences in the host immune system further complicate the host repertoire leading to wide heterogeneity in the clinical picture, course and outcome.COVID-19 is a heterogeneous disease spectrum with manifestations varying with age and comorbidities. Blood biomarkers play crucial role in early diagnosis in suspicion, monitoring, and recognition of complications and management of patients. Testing panels of blood biomarkers, rather than single biomarker may provide more reliable information. ${ }^{\mathbf{1}}$

Strategies for Diagnosis of Clinical COVID-19 and IV Artesunate Therapy

Patients having RAT and RT-PCR test negative reports directly admitted in the indoor department of general medicine or shifted from COVID-19 isolation wards ,clinically still suspected to have COVID-19 infection were diagnosed as clinical COVID-19, if they met $\geq 1$ one of the following diagnostic criteria i.e. elevated inflammatory markers i.e. serum LDH, CRP, Ferritin and coagulation dysfunction i.e. D-dimer levels and 
decreased lymphocyte, eosinophils and platelet counts, and/or with X-ray and HRCT chest findings. Severity of infection was determined clinically and after obtaining inform consent from patient or his/her relatives, empirical Artesunate $4 \mathrm{mg} / \mathrm{kg}$ IV bolus (in 2-10 minute) was administered twice daily for five days. Morbidity and mortality outcome and adverse reactions, if any were noted during the hospital stay. Further COVID-19 specific serologic antibodies tests for $\mathrm{TAb}, \mathrm{IgM}$, and $\mathrm{IgG}$ were done at appropriate time to confirm the final diagnosis.

Table 1 Clinical profiles of Rapid Antigen and RT-PCR test negative moderate to severe hospitalized Clinically Proven COVID-19 patients and their outcome with IV Bolus Artesunate Therapy

\begin{tabular}{|c|c|c|c|c|c|c|c|c|c|c|c|}
\hline Sr.No & Age & Sex & $\begin{array}{c}\text { Co- } \\
\text { morbidity }\end{array}$ & $\begin{array}{c}\text { Symptoms \& signs on } \\
\text { presentation }\end{array}$ & $\begin{array}{c}\text { Ferritin } \\
\text { ng/ml }\end{array}$ & $\begin{array}{l}\text { LDH } \\
\text { IU/L }\end{array}$ & $\begin{array}{l}\text { CRP } \\
\mathrm{mg} / \mathrm{L}\end{array}$ & $\begin{array}{c}\text { D- } \\
\text { dimer } \\
\text { mg/L }\end{array}$ & $\begin{array}{c}\mathrm{X}- \\
\text { Ray/HRCT }\end{array}$ & $\begin{array}{l}\text { Antibody } \\
\text { OD ratio }>1 \\
\text { +ve }\end{array}$ & Outcome \\
\hline 1 & 48 & $\mathrm{M}$ & $\begin{array}{l}\text { Cirrhosis of } \\
\text { liver \& CKD }\end{array}$ & $\begin{array}{c}\text { Jaundice-1 month. Fever- } \\
4 \text { days, Abdomen } \\
\text { distension \& pain } 1 \text { day }\end{array}$ & $\begin{array}{l}>2000 \& \\
>1000\end{array}$ & $\begin{array}{c}656 \& \\
513\end{array}$ & 70.7 & $\begin{array}{c}>5 \& \\
4.2\end{array}$ & $\begin{array}{c}\mathrm{L} / \mathrm{L} \\
\text { Pneumonia }\end{array}$ & $\begin{array}{c}\text { RT-PCR } \\
+ \text { ve,IgG+ve- } \\
23.9\end{array}$ & $\begin{array}{l}\text { Improved \& } \\
\text { survived }\end{array}$ \\
\hline 2 & 64 & $\mathrm{M}$ & $\begin{array}{l}\text { T2DMCKD, } \\
\text { HTN }\end{array}$ & $\begin{array}{l}\text { SOB , Oedema, CHF-7 } \\
\text { days }\end{array}$ & $>1000$ & 1239 & 24 & 20 & $\begin{array}{l}\mathrm{B} / \mathrm{L} \text { GGO } \\
\& \\
\text { Cardiomeg } \\
\text { ally }\end{array}$ & IgG +ve & $\begin{array}{l}\text { Improved \& } \\
\text { survived }\end{array}$ \\
\hline 3 & 60 & $\mathrm{~F}$ & $\begin{array}{c}\text { T2DM } \\
\text { HTN,CCF, } \\
\text { CKD }\end{array}$ & $\begin{array}{l}\text { Cough, fever, SOB, } \\
\text { Upper GI-bleed, LL } \\
\text { DVT-5 days }\end{array}$ & $\begin{array}{l}463 \& \\
>1000\end{array}$ & $\begin{array}{c}867 \& \\
688\end{array}$ & $\begin{array}{l}82 \& \\
10.1\end{array}$ & 9.3 & $\begin{array}{c}\text { B/L-GGO, } \\
\text { Pulmonary } \\
\text { Oedema }\end{array}$ & $\begin{array}{c}\text { IgG +ve - } \\
9.31 . . \text { IgM- } \\
\text { +ve-2.98 }\end{array}$ & $\begin{array}{c}\text { Improved \& } \\
\text { survived }\end{array}$ \\
\hline 4 & 54 & $\mathrm{M}$ & DM HTN & Fever,SOB-4 days & $\begin{array}{l}>1000 \\
\& 1000\end{array}$ & $\begin{array}{c}403 \& \\
1855\end{array}$ & $\begin{array}{c}182 \& \\
200\end{array}$ & $\begin{array}{c}0.1 \& \\
2.8\end{array}$ & $\begin{array}{c}\text { Rt.LLP, } \\
\text { Multiple } \\
\text { B/L GGO of } \\
\text { lungs } \\
\end{array}$ & $\begin{array}{l}\text { IgG-+VE- } \\
6.61, \mathrm{TAb}- \\
5.34+\mathrm{VE}\end{array}$ & $\begin{array}{c}\text { improved \& } \\
\text { survived }\end{array}$ \\
\hline 5 & 52 & $\mathrm{M}$ & T2DM & $\begin{array}{c}\text { Fever -5 days, SOB- } \\
\text { 3days }\end{array}$ & $\begin{array}{c}1092 \& \\
748\end{array}$ & $\begin{array}{c}233 \& \\
787\end{array}$ & $\begin{array}{l}58 \& \\
26.3\end{array}$ & $\begin{array}{c}228 \& \\
2.0\end{array}$ & $\begin{array}{l}\mathrm{B} / \mathrm{L} \text { patchy } \\
\text { Pneumonia }\end{array}$ & $\begin{array}{c}\text { IgG+ve- } 2.3 \\
\text { \&TAb+ve- } \\
2.88\end{array}$ & $\begin{array}{l}\text { survived \& } \\
\text { improved }\end{array}$ \\
\hline 6 & 30 & $\mathrm{M}$ & SCD & $\begin{array}{c}\text { G. Weakness-5 days, } \\
\text { SOB-1 day }\end{array}$ & $\begin{array}{l}>1000 \\
\& 100\end{array}$ & $\begin{array}{c}1449 \& \\
2878\end{array}$ & $\begin{array}{c}47 \\
\& 85\end{array}$ & $13 \& 8.5$ & $\mathrm{CHF}$ & $\operatorname{IgG}+\mathrm{ve}$ & $\begin{array}{c}\text { survived \& } \\
\text { improved }\end{array}$ \\
\hline 7 & 28 & $\mathrm{M}$ & $\begin{array}{l}\text { Cirrhosis of } \\
\text { liver }\end{array}$ & $\begin{array}{l}\text { Abdominal pain \& } \\
\text { Distension-7 days }\end{array}$ & $\begin{array}{c}640 \& \\
\text { on } 5^{\text {th }} \text { day } \\
523\end{array}$ & $\begin{array}{c}560 \& \\
\text { on } 5^{\text {th }} \\
\text { day } 316\end{array}$ & $\begin{array}{c}3.9 \& \text { on } \\
5^{\text {th }} \text { day } \\
10\end{array}$ & $\begin{array}{c}3.0 \& \\
\text { on } 5^{\text {th }} \\
\text { day } \\
12.1\end{array}$ & $\begin{array}{l}\text { B/L Pleural } \\
\text { Effusion }\end{array}$ & IgG +ve & $\begin{array}{c}\text { survived \& } \\
\text { improved }\end{array}$ \\
\hline 8 & 50 & $\mathrm{M}$ & $\begin{array}{l}\text { Cirrhosis of } \\
\text { liver }\end{array}$ & $\begin{array}{l}\text { Fever \& Distension of } \\
\text { Abdomen-5 days }\end{array}$ & $\begin{array}{l}869 \& \\
728\end{array}$ & $\begin{array}{c}831 \\
\& 916\end{array}$ & $32 \& 30$ & $\begin{array}{c}8.5 \& \\
9.0\end{array}$ & $\begin{array}{l}\text { Ascites \& } \\
\text { PHTN }\end{array}$ & $\begin{array}{c}\mathrm{IgG}+\mathrm{ve}- \\
2.74\end{array}$ & $\begin{array}{c}\text { survived \& } \\
\text { improved }\end{array}$ \\
\hline 9 & 54 & $\mathrm{M}$ & & Fever-3 \& Cough 7 days & $\begin{array}{l}884 \& \\
>1000\end{array}$ & $\begin{array}{c}1205 \& \\
1058\end{array}$ & $\begin{array}{c}104.1 \& \\
62.4\end{array}$ & $\begin{array}{c}0.5 \& \\
1.7\end{array}$ & $\begin{array}{l}\text { Ascites \& } \\
\text { PHTN }\end{array}$ & $\begin{array}{l}\text { TAb +ve- } \\
5.87 \& \operatorname{IgG} \\
+ \text { ve } 3.84\end{array}$ & $\begin{array}{l}\text { survived \& } \\
\text { improved }\end{array}$ \\
\hline 10 & 40 & $\mathrm{M}$ & Gout? & Gen. Arthritis -25 days & $\begin{array}{c}540 \& \\
1000\end{array}$ & $\begin{array}{c}290 \& \& \\
628\end{array}$ & $\begin{array}{c}117 \\
\& 120\end{array}$ & $\begin{array}{c}0.5 \& \\
1.5\end{array}$ & $\begin{array}{l}\text { Hyperurice } \\
\text { mia }\end{array}$ & $\begin{array}{c}\mathrm{TAb}+\mathrm{ve} \\
>10 \& \mathrm{IgG} \\
0.12\end{array}$ & $\begin{array}{l}\text { improved \& } \\
\text { survived }\end{array}$ \\
\hline 11 & 45 & $\mathrm{M}$ & Nil & $\begin{array}{c}\text { Fever, chest pain, SOB -7 } \\
\text { days, Left Hemiparesis } 1 \\
\text { day }\end{array}$ & $\begin{array}{c}414 \& \\
5^{\text {th }} \text { day } \\
771\end{array}$ & $\begin{array}{c}538 \& \\
5^{\text {th }} \text { day } \\
749\end{array}$ & 5.9 & $\begin{array}{c}10 \& 5^{\text {th }} \\
\text { day } \\
2121\end{array}$ & $\begin{array}{c}\text { Ischemic } \\
\text { stroke Rt. } \\
\text { MCA \& } \\
\text { HRCT- } \\
\text { GGO Rt. } \\
\text { lung, mild } \\
\text { Rt.PE }\end{array}$ & $\begin{array}{c}\text { IgG+VE- } \\
5.92, \text { Tab+ve }\end{array}$ & $\begin{array}{l}\text { improved \& } \\
\text { survived }\end{array}$ \\
\hline 12 & 40 & $\mathrm{M}$ & $\begin{array}{l}\text { Cirrhosis of } \\
\text { liver }\end{array}$ & $\begin{array}{c}\text { Abdominal Distension -2 } \\
\text { months, Epistaxis }-15 \\
\text { days, }\end{array}$ & 519 & 279 & & 20 & $\begin{array}{c}\text { Ascites \& } \\
\text { PHTN }\end{array}$ & $\begin{array}{c}\text { IgG +VE- } \\
16.65 \\
\text { TAb+ve }\end{array}$ & $\begin{array}{l}\text { Improved \& } \\
\text { Survived }\end{array}$ \\
\hline 13 & 62 & $\mathrm{~F}$ & DM HTN & $\begin{array}{l}\text { Breathlessness- } 2 \text { months, } \\
\text { cough }-2 \text { month }\end{array}$ & $\begin{array}{c}70 \& \\
3^{\text {rd }} \text { day } 74\end{array}$ & $\begin{array}{l}431 \& 3^{\text {rd }} \\
\text { day } 440\end{array}$ & $\begin{array}{c}9.4 \& \\
3 \text { rs day } \\
<5\end{array}$ & $\begin{array}{l}0.2 \& 3^{\text {rd }} \\
\text { day } 0.8\end{array}$ & $\begin{array}{l}\text { L/L lung } \\
\text { Patchy } \\
\text { opacities } \\
\end{array}$ & $\begin{array}{c}\text { IgG+VE } \\
7.2, \text { Tab+ve }\end{array}$ & $\begin{array}{c}\text { improved \& } \\
\text { survived }\end{array}$ \\
\hline 14 & 65 & $\mathrm{M}$ & NIL & $\begin{array}{c}\text { Fever-1 day, Cough \& } \\
\text { SOB-5days,PaO2 } \\
89 \%(\mathrm{RA})\end{array}$ & 181 & 698 & 116 & 0.2 & $\begin{array}{l}\text { B/L Lower } \\
\text { zone GGO }\end{array}$ & $\mathrm{IgG}+\mathrm{VE}$ & $\begin{array}{c}\text { SOB decreased } \\
\text { on } 3^{\text {rd }} \text { day,PaO2 } \\
94 \% \text { (RA) \& } \\
\text { survived }\end{array}$ \\
\hline 15 & 53 & $\mathrm{M}$ & $\begin{array}{l}\text { Cirrhosis } \\
\text { Alco }\end{array}$ & $\begin{array}{c}\text { Increase Abdominal } \\
\text { distension \& Hiccough- } 8 \\
\text { days }\end{array}$ & 697 & 471 & 70 & 11.7 & $\begin{array}{c}\text { Ascites- } \\
\text { Exudative }\end{array}$ & $\begin{array}{l}\text { IgG+VE- } \\
\text { 3.24.TAB- } \\
\text { 5.26 }\end{array}$ & $\begin{array}{l}\text { Stable \& } \\
\text { survived }\end{array}$ \\
\hline
\end{tabular}




\begin{tabular}{|c|c|c|c|c|c|c|c|c|c|c|c|}
\hline 16 & 70 & $\mathrm{M}$ & HTN,DCM & $\begin{array}{c}\text { SOB , Abdominal } \\
\text { distension, puffy face- } \\
\text { 3days }\end{array}$ & 143.9 & 299 & 46.93 & 4043.96 & $\begin{array}{l}\text { Cardiomegal } \\
\text { ly, mild PE } \\
\& \\
\text { pericardial } \\
\text { effusion. } \\
\text { EF- } 62 \%, \\
\text { good LVF }\end{array}$ & & $\begin{array}{l}\text { Improved \& } \\
\text { stable }\end{array}$ \\
\hline 17 & 50 & $\mathrm{M}$ & NIL & $\begin{array}{l}\text { SOB-2 months, Fever, } \\
\text { pain abdomen }-4 \text { days }\end{array}$ & 245 & 495 & $<5$ & 1.7 & $\begin{array}{l}\text { Cardiomegal } \\
\text { ly, mild B/L } \\
\mathrm{PE}, \text { Ascites, } \\
\text { pericardial } \\
\text { effusion, } \\
\text { hepatosplen } \\
\text { omegally }\end{array}$ & $\begin{array}{c}\text { IgG- } \\
1.78, \mathrm{TAb}- \\
3.74+\mathrm{ve}\end{array}$ & $\begin{array}{l}\text { Stable \& } \\
\text { survived }\end{array}$ \\
\hline 18 & 38 & $\mathrm{M}$ & NIL & $\begin{array}{l}\text { Chest pain, palpitation, } \\
\text { sweating-3 days. }\end{array}$ & & & & $\begin{array}{l}40000 \\
\& 3^{\text {rd }} \\
\text { day } \\
13693\end{array}$ & $\begin{array}{l}\text { Ant. Wall } \\
\text { AMI }\end{array}$ & $\begin{array}{l}\text { IgG-1.70 } \\
+ \text { +ve }\end{array}$ & $\begin{array}{c}\text { Stable \& } \\
\text { survived \& } \\
\text { discharged }\end{array}$ \\
\hline 19 & 33 & $\mathrm{M}$ & NIL & $\begin{array}{c}\text { Diarrhoea } 4 \text { episode } 20 \\
\text { days back, weakness of } \\
\text { extremities-10 days. } \\
\text { (GBS?) }\end{array}$ & 817 & 555 & $<5$ & 6.1 & $\begin{array}{c}\text { Baseline } \\
\text { weakness- } \\
3 / 5 \text {, after } 5 \\
\text { days- } 4 / 5\end{array}$ & $\begin{array}{l}\text { IgG-+ve - } \\
3.25\end{array}$ & $\begin{array}{c}\text { Improved \& } \\
\text { discharged }\end{array}$ \\
\hline 20 & 56 & $\mathrm{M}$ & $\begin{array}{l}\text { Alcoholic } \\
\text { Liver } \\
\text { Disease }\end{array}$ & $\begin{array}{l}\text { Abdominal Distension } 10 \\
\text { days, hiccough-7 days. } \\
\text { Ascites, thickened } \\
\text { Omentum -TB peritonitis? }\end{array}$ & 657 & 417 & 70 & 11.7 & $\begin{array}{l}\text { Ascites \& } \\
\text { PHTN }\end{array}$ & $\begin{array}{c}\text { IgG +ve- } \\
3.24, \mathrm{TAB}+\mathrm{v} \\
\mathrm{e}-5.26 \text { on } \\
14^{\text {th }} \text { day } \\
\text { from } \\
\text { symptoms } \\
\text { onset } \\
\end{array}$ & Improved \\
\hline 21 & 70 & $\mathrm{M}$ & DCM & $\begin{array}{l}\text { Swelling abdomen } \& \\
\text { pedal edema-15 days, } \\
\text { SOB-10 days.CCF, Rt. } \\
\text { Side exudative pleural } \\
\text { effusion. }\end{array}$ & 463 & 799 & $<5$ & 1.9 & $\begin{array}{l}\text { DCM with } \\
\text { features of } \\
\text { CHF }\end{array}$ & $\begin{array}{c}\text { IgG+ve- } \\
1.27, \mathrm{TAB} \\
+\mathrm{ve}-1.33 \text { on } \\
18^{\text {th }} \text { day } \\
\text { from onset } \\
\text { of } \\
\text { symptoms } \\
\end{array}$ & Improved \\
\hline 22 & 33 & $\mathrm{~F}$ & ESRD.HTN & $\begin{array}{l}\text { H/O Fever } 5 \text { days } 1 \\
\text { month back. Vomiting } \\
\text { altered sensorium, } \\
\text { decreased urination-4 } \\
\text { days, } \& \\
\text { dyselectrolytemia. }\end{array}$ & 678 & & 5 & 1.3 & $\begin{array}{l}\text { Conscious } \\
\text { with } \\
\text { increased } \\
\text { urination }\end{array}$ & $\begin{array}{c}\text { IgG +ve- } \\
3.33\end{array}$ & $\begin{array}{l}\text { Improved \& on } \\
\text { haemodialysis. }\end{array}$ \\
\hline 23 & 57 & $\mathrm{M}$ & $\begin{array}{l}\text { HTN,COPD } \\
\text { NASH }\end{array}$ & $\begin{array}{c}\text { Diarrhoea-8 days, } \\
\text { vomiting \& SOB-2 days. } \\
\mathrm{PaO} 2-70 \%(\mathrm{RA})\end{array}$ & 178.3 & 583 & 75 & & $\begin{array}{c}\text { Hypokalemi } \\
-\mathrm{a}\end{array}$ & $\begin{array}{c}\text { IgG +ve- } \\
17.5, \mathrm{TAb} \\
+\mathrm{ve}-2.88 \text { on } \\
10^{\text {th }} \text { day }\end{array}$ & Improved \\
\hline 24 & 65 & $\mathrm{~F}$ & CKD, COPD & $\begin{array}{c}\text { Fever } 3 \text { days } 1 \text { moth back, } \\
\text { Generalized anasarca } 1 \\
\text { month, Oliguria } 10 \text { days } \\
\& \text { SOB } 7 \text { days } \mathrm{SpaO} 2 \\
89 \%(\mathrm{RA}) .\end{array}$ & 273 & 406 & 32 & 0.2 & $\begin{array}{c}\mathrm{PaO} 298 \% \\
\text { after } 5 \text { days } \\
\text { with } \\
\text { adequate } \\
\text { urination. } \\
\end{array}$ & $\begin{array}{l}\text { IgG-0.8 } \\
\& \mathrm{TAb}-+\mathrm{ve} \\
3.77 \text { on } 10^{\text {th }} \\
\text { day test }\end{array}$ & $\begin{array}{l}\text { Markedly } \\
\text { improved \& on } \\
\text { dialysis. }\end{array}$ \\
\hline 25 & 69 & $\mathrm{~F}$ & $\begin{array}{c}\text { CKD,HTN,C } \\
\text { CF }\end{array}$ & $\begin{array}{c}\text { SOB-5 days, cough-2 } \\
\text { days, edema both leg- } 5 \\
\text { days. } \mathrm{PaO} 2-82 \% . \mathrm{B} / \mathrm{L} \mathrm{PE} \text {. }\end{array}$ & 270 & 492 & 80 & 0.04 & $\begin{array}{l}\mathrm{PaO} 2-98 \% \\
\text { after } 4 \text { days }\end{array}$ & $\begin{array}{c}\text { IgG-2.57 } \\
+ \text { +ve \& TAb- } \\
5.52+\text { ve on } \\
10^{\text {th }} \text { day. }\end{array}$ & Improved. \\
\hline 26 & 22 & $\mathrm{~F}$ & & $\begin{array}{c}\text { fever with chills for } 5 \\
\text { days } 12 \text { days back ,SOB } \\
\text { for } 6 \text { days, vomiting and } \\
\text { fever for } 1 \text { day }\end{array}$ & 413 & 299 & 64.32 & 13061 & $\begin{array}{c}\text { Fever, } \\
\text { vomiting } \\
\text { subsided } \\
\text { after } 48 \mathrm{hr}\end{array}$ & $\begin{array}{l}\text { TAb-1.66 } \\
\text { and IgG- } \\
10.25 \text { OD }\end{array}$ & Improved. \\
\hline 28 & 72 & $\mathrm{M}$ & T2DM & $\begin{array}{c}\text { Fever, loss of appetite } 15 \\
\text { days,SOB,PaO2-88\%,\& } \\
\text { CHF }\end{array}$ & 260 & $\begin{array}{l}291 \\
\text { IU/L }\end{array}$ & 10 & $\begin{array}{c}0.1 \mathrm{mg} / \\
\mathrm{L}\end{array}$ & $\begin{array}{l}\text { X-ray \& CT } \\
\text { +ve GGO }\end{array}$ & $\begin{array}{c}\text { IgM +ve } \\
4.33 \& \mathrm{IgG} \\
+\mathrm{ve}-7.54 \\
\end{array}$ & Improved \\
\hline 29 & 53 & $\mathrm{M}$ & Br. Asthma & $\begin{array}{l}\text { Fever, cough } 15 \text { days, } \\
\text { SOB } 3 \text { days, } \mathrm{PaO} 2-94 \%\end{array}$ & 445 & 698 & 84 & $<0.1$ & $\begin{array}{l}\mathrm{PaO} 2-96 \% \\
3^{\text {rd }} \text { day }\end{array}$ & $\begin{array}{l}\text { IgG +ve } 20 \\
\text { Index \& } \\
\text { TAb +ve } \\
7.01 \text { OD } \\
\text { ratio }\end{array}$ & $\begin{array}{c}\text { Improved \& } \\
\text { discharged on } 5^{\text {th }} \\
\text { day }\end{array}$ \\
\hline 30 & 42 & $\mathrm{~F}$ & & $\begin{array}{c}\text { Fever } 7 \text { days, altered } \\
\text { sensorium } 1 \text { day with h/o } \\
\text { pf +ve. }\end{array}$ & $\begin{array}{c}466 \& \\
360 \\
5^{\text {th }} \text { day }\end{array}$ & 500 & $\begin{array}{c}28.25 \& \\
5.2 \text { on } \\
5^{\text {th }} \text { day }\end{array}$ & $\begin{array}{l}5.65 \& \\
1.93 \text { on } \\
5^{\text {th }} \text { day }\end{array}$ & $\begin{array}{c}\text { X-ray chest } \\
\text { B/L } \\
\text { peripheral } \\
\text { GGO } \\
\text { HRCT- } \\
\text { CORAD- } 4 \\
\end{array}$ & $\begin{array}{l}\text { Follow up } \\
14^{\text {th }} \text { day IgM } \\
\text { +ve } 1.5\end{array}$ & $\begin{array}{l}\text { Improved \& } \\
\text { survived }\end{array}$ \\
\hline 31 & 19 & $\mathrm{M}$ & NIL & $\begin{array}{l}\text { Fever-21days \& Gen - } \\
\text { weakness- } 7 \text { days }\end{array}$ & 852 & 879 & 45.3 & 0.13 & $\begin{array}{l}\text { Pallor+++,pf } \\
\text {-ICT +ve, } \\
\text { MP-QBC-ve }\end{array}$ & $\begin{array}{l}\text { IgM-1.32 } \\
+ \text { +ve }\end{array}$ & $\begin{array}{l}\text { Improved \& } \\
\text { survived }\end{array}$ \\
\hline
\end{tabular}




\section{Cases Presentation}

Case 1 A 48 years old male alcoholic cirrhosis of liver and CKD with COVID-19 RT-PCR positive history 3 moths back presented with yellow coloration of urine and jaundice for 2 months, fever for 4 days and abdominal distension 1 day. On investigation haemoglobin was $8.7 \mathrm{gm} \%$, TLC $14.14 \times 10^{3} / \mu \mathrm{L}$, neutrophils $84 \%$, lymphocyte$8.4 \%$, serum ferritin was >2000ng/ml, LDH 656 IU/L,CRP-70mg/L,7, D-dimer $5 \mathrm{mg} / \mathrm{L}$, serum urea $93 \mathrm{mg} / \mathrm{dl}$, creatinine $-3.7 \mathrm{mg} / \mathrm{dl}$, serum albumin $2.7 \mathrm{mg} / \mathrm{dl}$, total serum bilirubin was raised $12.32 \mathrm{mg} / \mathrm{dl}$ with mildly elevated transaminases levels. X-ray chest showed left lower lobe pneumonia and HRCT showed ground glass opacities (GGO). Bolus IV Artesunate $4 \mathrm{mg} / \mathrm{kg}$ administered twice daily for 5 days and received 3 blood transfusions. Fever subsided after 3 days and patient felt better. Follow up serum ferritin after $5^{\text {th }}$ day was $1000 \mathrm{ng} / \mathrm{ml}, \mathrm{LDH}-513 \mathrm{IU} / \mathrm{L}$ and D-dimer $\quad 4.25 \mathrm{ng} / \mu \mathrm{L}$. COVID-19 specific antibodies (ELISA) IgG -23.90 and IgM 0.67 OD ratios positive. This was a case of severe long COVID-19 syndrome with cirrhosis of liver with CKD.

Case 2 A 64 years old male presented with shortness of breaths (SOB) and swelling of both feet for 7 days. On examination pulse rate 100/min, $\mathrm{PaO} 2$ was $86 \%$ with room air (RA), Respiratory Rate (RR)- 28/min. On investigation TLC was $1200 / \mu \mathrm{L}$, serum Na+ $-123 \mathrm{mEq} / \mathrm{L}, \mathrm{K}+-$ $3.2 \mathrm{mEq} / \mathrm{L}$, Ferritin $>1000 \mathrm{ng} / \mathrm{ml}$, LDH-1239 IU/L, CRP-26mg/L, D-dimer-20mg/L. X-ray chest revealed peripheral lesions characteristic of COVID-19 with cardiomegally. Treated with IV Artesunate for 5 days along with standard treatment of heart failure. All symptoms improved after 5 days and covid-19 specific IgM and IgG antibody were positive (qualitative). This was a case of underlying cardiomyopathy and severe acute COVID-19 infection with hypokelaemia and CHF.

Case 3 A 60 years old female with h/o T2DM, hypertension, CKD presented with history of cough, fever, SOB and upper GI bleeding for 5 days. On examination BP-130/70mmHg, pulse100/min,RR-28/min,PaO2-94\% (RA). On investigation $\quad \mathrm{TLC}-13,15 \mathrm{X} 10^{3} / \mathrm{L}, \mathrm{N}-70.8 \%$,L22.9\%, Serum ferritin-463ng/ml, LDH-867 IU/L, CRP-82 mg/L , D-dimer-9.3 mg/L, serum urea$80 \mathrm{mg} / \mathrm{dl}$ and creatinine $-2.4 \mathrm{mg} / \mathrm{dl}$ and on $3^{\text {rd }}$ day ferritin level 1000ng/ml, LDH 688IU/L and CRP$101 \mathrm{mg} / \mathrm{L}$. HRCT of thorax showed bilateral GGO with pulmonary oedema. Treated with IV Artesunate for 5 days and symptoms improved markedly. Follow up COVID-19 antibody tests positive for IgG-9.31 and IgM-2.98 OD ratio. This was a case of moderately severe acute COVID-19 infection.

Case 4 A 54 years old T2DM and HTN male presented with fever and SOB for 4 days. On presentation, BP-140/90mmHg, pulse-96/min. RR-36/min, PaO2-94\%(RA), x-ray chest showed right lower lobe GGO and HRCT- multiple GGO bilaterally, CT severity score of 10/25 .Baseline serum ferritin level was >1000ng/ml, LDH-403 IU/L,CRP-182 mg/L ,D-dimer $0.1 \mathrm{mg} / \mathrm{L}$. Patient treated with IV Artesunate and symptoms improved within 5 days. Follow up Ferritin on $3^{\text {rd }}$ day was $>1000 \mathrm{ng} / \mathrm{ml}$, LDH -1855 IU/L, CRP-100 $\mathrm{mg} / \mathrm{L}$, D-dimer-2.8 mg/L. Follow up COVID-19 antibodies tests positive for IgG-6.61 and TAb5.34 OD ratio. This was a case of moderately severe acute COVID-19 infection.

Case 5 A 52 years old male presented with fever for 5 days and SOB for 3 days with h/o T2DM. On examination BP-110/70 mmHg, pulse-92/min, RR-30/min, PaO2-98 \%( RA).On investigations TLC-7.9X10 ${ }^{3} / \mathrm{L}, \mathrm{TPC}-2.3 / \mu \mathrm{L}, \mathrm{Hb}-12 \mathrm{gm} \%$. Serum ferritin-1092ng/ml, LDH-233 IU/L， CRP-58 $\mathrm{mg} / \mathrm{L}, \mathrm{D}$-dimer-228 mg/L .Chest x-ray- bilateral patchy GGO. Treated with IV Artesunate along with other standard treatment and symptoms improved and follow up ferritin level on $5^{\text {th }}$ day decreased to $748 \mathrm{ng} / \mathrm{ml}$, LDH-increased to 787IU/L, CRP-decreased to $26.3 \mathrm{mg} / \mathrm{L}$ and Ddimer-to $2.0 \mathrm{mg} / \mathrm{L}$. Follow up antibodies were positive for IgG-2.3 and TAb-2.8 OD ratio. This was a moderately severe acute covid-19 infection with T2DM. 
Case 6 A 30 years old male known sickle cell disease(SS), presented with general weakness for 5 days, polyathralgia and SOB for 1 day .On examination BP-130/80 mmHg, pulse-98/min, $\mathrm{PaO} 2-90 \%$ (RA). On investigations serum ferritin was >1000ng/ml, LDH-1949 IU/L, CRP-47 mg/L, D-dimer-13 $\mathrm{mg} / \mathrm{L}$ and IV Artesunate administered for 5 days. Patient's oxygen saturation increased with symptoms improvement. Follow up serum ferritin on $5^{\text {th }}$ day was to 100ng/ml, LDH-2878 IU/L, CRP-85 mg/L ,Ddimer- $8.5 \mathrm{mg} / \mathrm{L}$. Follow up antibody was positive for IgM and $\mathrm{IgG}$. This was a case of severe acute COVID-19 infection precipitated Vaso-occlusive Crisis in sickle cell disease.

Case.7. A 28 years old male, known alcoholic cirrhosis of liver presented with distension and pain abdomen for 7 days. On examinations BP110/70 mmHg, pulse-80/min, $\mathrm{PaO} 2-97 \%$. TLC4000/ $\mu \mathrm{L} . \quad$ TPC-66000, Hb-9.7gm\%,Na+$138 \mathrm{mEq} / \mathrm{L}, \mathrm{K}+-3.4 \mathrm{mEq} / \mathrm{L}$. Serum ferritin level was 640ng/ml, LDH-560 IU/L, CRP-3.9 mg/L, Ddimer-3.0 mg/L , x-ray chest-B/L pleural effusion. COVID-19 IgG antibody was positive. Follow up ferritin after 5 days was $523 \mathrm{ng} / \mathrm{ml}$, LDH-316 IU/L, CRP-10 mg/L and D- dimer $-12.1 \mathrm{mg} / \mathrm{L}$. Patient's symptoms improved with 5 days of Artesunate therapy. This was a case of moderately severe acute COVID-19 infection with cirrhosis of liver.

Case 8 A 50 years old known male alcoholic cirrhosis of liver presented with fever and distension of abdomen for 5 days. On investigation serum ferritin was $867 \mathrm{ng} / \mathrm{ml}$, LDH$831 \mathrm{IU} / \mathrm{L}, \mathrm{CRP}-32 \mathrm{mg} / \mathrm{L}$, and D-dimer was 8.9 $\mathrm{mg} / \mathrm{L}$. After 5 days of Artesunate therapy along with standard therapy, patient's symptoms improved and serum ferritin was 728ng/ml, LDHwas $916 \mathrm{IU} / \mathrm{L}, \mathrm{CRP}-30 \mathrm{mg} / \mathrm{L}$ and D-dimer was 9 $\mathrm{mg} / \mathrm{L}$. Follow up IgG antibody test done was positive (2.74 OD ratio) . This was a moderately severe acute COVID-19 infection with cirrhosis of liver.

Case 9 A 54 years old male chronic alcoholic presented with h/o fever for 3 days and cough for
7 days with alcohol withdrawal syndrome. On examination BP-80/50mmHg, pulse-128/min, $\mathrm{PaO} 2-94 \% \quad$ (RA), RR-19/min. On routine blood

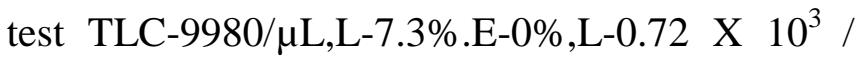
$\mu \mathrm{L}, \quad \mathrm{TPC}-171000 / \mu \mathrm{L}, \quad \mathrm{Hb}-11.8 \mathrm{gm} \%$, Na+$143 \mathrm{mEq} / \mathrm{L}, \mathrm{K}+-2.6 \mathrm{mEq} / \mathrm{L}$. Baseline serum ferritin was $884 \mathrm{ng} / \mathrm{ml}, \mathrm{LDH}-1205$ IU/L,CRP-104 mg/L ,D-dimer-0.5mg/L . Follow up serum ferritin was $>$ 1000ng/L, LDH-1058 IU/L,CRP-62.4 mg/L, Ddimer-1.7 mg/L. Patient improved with IV Artesunate for 5 days and follow up antibodies were positive (TAb-5.87 and IgG-3.84 OD ratio). This was a case of moderately severe acute COVID-19 infection.

Case 10 A 40 years old male presented with severe generalized arthritis for 25 days. On examination BP-110/80 $\mathrm{mmHg}$,pulse-86/min,RR-

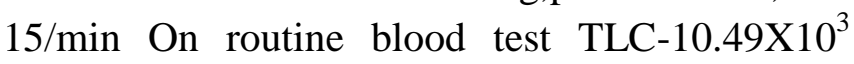
$/ \mu \mathrm{L}, \mathrm{E}-2 \%, \quad \mathrm{~L}-28 \%, \quad \mathrm{TPC}-460 \mathrm{X} 10^{3} / \mu \mathrm{L}, \mathrm{Hb}-$ 10.3gm\%， Na+-139mEq/L， K+-4.0mEq/L. Baseline serum ferritin was 540ng/ml,LDH-290 IU/L, CRP-117mg/L ,D-dimer-0.5 mg/L. After 3rd day of Artesunate therapy repeat ferritin was 1000ng/ml, LDH-628 IU/L, CRP-120 mg/L , Ddimer-1 mg/L and serum uric acid was $10 \mathrm{mg} / \mathrm{dl}$. Patient improved with IV Artesunate therapy. Follow up antibody positive for $\mathrm{TAb}>10$ and IgG-0.12 OD ratio. This was a case of moderately severe acute COVID-19 infection with hyperuricemia.

Case 11 A 45 years old male presented with h/o intermittent fever, chest pain, SOB for 7 days and weakness of left upper and lower limb for one day with altered sensorium .CT scan of brain showed Rt. Side MCA territory ischemic infarction. On examination BP-140/90mmHg, pulse-84/min, $\mathrm{PaO} 2-88 \%$ (RA), and $98 \%$ with $2 \mathrm{~L} / \mathrm{min} \mathrm{O}_{2}$ therapies put on artificial ventilation for $>5$ days. On routine test TLC- $11.8 \times 10^{3} / \mu \mathrm{L}, \mathrm{N}-84 \%, \mathrm{~L}-$ $7.5 \%, \quad \mathrm{E}-0.3 \%, \mathrm{M}-3.3 \%$, TPC- $179 \times 10^{3} / \mu \mathrm{L}, \mathrm{Hb}-$ $11.79 \mathrm{gm} \%, \quad \mathrm{~K}+-3.8 \mathrm{mEq} / \mathrm{L}, \mathrm{Na}+-140 \mathrm{mEq} / / \mu \mathrm{L}$. Baseline Serum ferritin was $414 \mathrm{ng} / \mathrm{ml}, \mathrm{LDH}-538$ IU/L,CRP-5.9 mg/L,D-dimer >10,000 mg/L. After 5 days of Artesunate therapy repeat D-dimer test was $2121 \mathrm{mg} / \mathrm{L}$, Troponin -I was $116 \mathrm{ng} / \mathrm{ml}$ and 
CPK-MB was 15 IU. After seven days ,repeat ferritin level was $771 \mathrm{ng} / \mathrm{ml}, \mathrm{LDH}-749$ IU/L,CRP $<5 \mathrm{mg} / \mathrm{L}$,D-dimer-3.2 mg/L.HRCT of thorax done after $15^{\text {th }}$ day showed $\mathrm{B} / \mathrm{L}$ upper and superior segment of lower lobe fibrocalcification suggestive of old PTB and diffused GGO in Rt. lung field with cardiomegally and mild pleural effusion and fissural collection of fluid. Ultimately patient recovered. Follow up antibodies test for COVID-19 was positive for IgG-5.92 OD ratio after 21th day. This was a case of critically severe acute COVID-19 infection with acute ischemic stroke in MCA territory.

Case 12 A 40 years old with known alcoholic cirrhosis presented with epistaxis and increasing abdominal distension for 15 days and $\mathrm{h} / \mathrm{o}$ fever with chill for 1 day 4 months back. On examination BP-110/70mmHg, PR- 80/min, $\mathrm{PaO} 2-99 \%$. On Routine blood test TLC13940/ $\mu \mathrm{L}, \mathrm{N}-73 \%, \mathrm{~L}-10.9 \%$, E-0\%,B-0.9\%, TPC$61000 / \mu \mathrm{L}, \mathrm{Hb}-9.3 \mathrm{gm} \%$. Baseline serum ferritin519ng/ml, LDH-279 IU/L, D-dimer-20 mg/L . Follow up repeat ferritin was $638 \mathrm{ng} / \mathrm{ml}$, LDH-354 IU/L. Patients improved with Artesunate therapy with resolution of symptoms and signs. Follow up IgG antibody for COVID-19 was positive (16.65 OD ratio) at the time of discharge. This may be a case of moderately severe prolonged COVID-19 infection in cirrhosis of liver with portal hypertension.

Case 13 A 62 years old female with h/o T2DM and HTN presented with cough and SOB for 2 months. On examination her BP was 120/70mmHg, pulse-84/min, $\mathrm{PaO} 2-94 \%$ ( RA) and RR-32/min. On routine blood test TLC$29340 / \mu \mathrm{L}$, lymphocyte $-1.5 \times 10^{3} / \mu \mathrm{L}$, TPC$308000 / \mu \mathrm{L}, \mathrm{Hb}-12 \mathrm{gm} \%$, serum $\mathrm{K}+3.3 \mathrm{mEq} / \mathrm{L}, \mathrm{Na}+$ $140 \mathrm{mEq} / \mathrm{L}$. Chest x-ray showed Left/LL patchy opacities. Serum ferritin at baseline was $70 \mathrm{ng} / \mathrm{ml}$, LDH-431 IU/L.CRP-9.4 mg/L, D-dimer-0.2mg/L. Repeat test for ferritin was 70ng/ml, LDH-440 IU/L, CRP was $<5 \mathrm{mg} / \mathrm{L}$. $\mathrm{PaO} 2$ increased to $98 \%$ (RA) on $3^{\text {rd }}$ day after Artesunate therapy along with decrease of breathlessness and cough and discharged on $7^{\text {th }}$ day. Follow-up COVID-19 antibody TAb and IgG was positive (16.6 and 20 OD ratio), suggested a case of moderately severe ongoing symptomatic COVID-19 infection.

Case 14 A 65 years old male presented with fever for 1 day, cough \& SOB for 5 days.On examination BP-120/74mmHg, pulse-86/min, $\mathrm{PaO} 2-89 \%$ (RA), and $96 \%$ with $\mathrm{O}_{2} 4 \mathrm{~L} / \mathrm{min} \&$ $94 \%$ on day 3 (RA).Baseline routine blood test TLC-6.9X10 ${ }^{3} / \mu \mathrm{L}, \mathrm{N}-74.8 \%, \mathrm{~L}-12.6 \%, \mathrm{M}-9.1 \%, \mathrm{E}-$ $3.2 \%, \quad \mathrm{~B}-0.3 \%, \mathrm{TPC}-203 \mathrm{X} 10^{3} / \mu \mathrm{L}, \mathrm{Hb}-11.19 \mathrm{gm} \%$, $\mathrm{Na}+-140 \mathrm{mEq} / \mathrm{L}, \mathrm{K}+-3.8 \mathrm{mEq} / \mathrm{L}$. Baseline serum ferritin $\quad-181 \mathrm{ng} / \mathrm{ml}, \quad$ LDH-698 IU/L,CRP-116 $\mathrm{mg} / \mathrm{L}$, D-dimer-0.2 mg/L , Chest x-ray-B/L Lower zone GGO. Follow up COVID-19 only antibody test done was positive for IgG +ve- 5.29 OD ratios. This was a moderate severe case of acute COVID-19 infection.

Case 15 A 53 years old male with chronic liver disease (alcoholic cirrhosis), with h/o repeated abdominal paracentesis for ascites presented with increased abdominal distension and hiccough for 8 days. On examination BP-118/80mmHg, pulse80/min, $\mathrm{PaO} 2-98 \%$, RR-14/min. On routine blood tests $\quad \mathrm{TLC}-5.17 \mathrm{X} 10^{3} / \mu \mathrm{L}, \mathrm{N}-3.5 \times 10^{3} \quad / \mu \mathrm{L}, \mathrm{L}-$ $0.50 \times 10^{3} \quad / \mu \mathrm{L}, \mathrm{TPC}-256 \times 10^{3} / \mu \mathrm{L}, \mathrm{Hb}-13.6 \mathrm{gm} \%$, $\mathrm{Na}+-130 \mathrm{mEq} / \mathrm{L}, \quad \mathrm{K}+-4.3 \mathrm{mEq} / \mathrm{L}$. Serum ferritin was $657 \mathrm{ng} / \mathrm{ml}$, LDH-477 IU/L,CRP-70 mg/L,Ddimer-11 mg/L. Ascitic fluid analysis showed exudative in nature with TLC-3000/ $\mu \mathrm{L}$ with lymphocytes predominance, total protein $4.15 \mathrm{gm} \%$, albumin-2.01gm\% and ADA postive 122 OD ratio. Patient improved with Artesunate therapy. Follow up antibody test positive for $\operatorname{IgM}$ and $\operatorname{IgG}$ (qualitative). This was a case of moderately severe acute COVID-19 infection reactivation of $\mathrm{TB}$ peritonitis.

Case 16 A 70 years old known Hypertensive male on Amlodipine $5 \mathrm{mg}$ daily, presented with h/o exertion dyspnoea and abdominal distension and puffy face for 3 days. On examination his BP was 140/80mmHg, pulse-100.min, $\mathrm{PaO} 2$ was $95 \%$ ( RA). Routine blood test showed TLC$7.5 \times 10^{3} / \mu \mathrm{L}, \mathrm{N}-4.76 \times 10^{3} / \mu \mathrm{L}, \mathrm{L}-1.92 \times 10^{3} / \mu \mathrm{L}$, TPC-220 X10 $3 / \mu \mathrm{L}, \mathrm{Hb}-10.9 \mathrm{gm} \% . \mathrm{Na}+-135 \mathrm{mEq} / \mathrm{L}$, $\mathrm{K}+-3.6 \mathrm{mEq} / \mathrm{L}$. Baseline serum ferritin was 
143.9ng/ml, LDH-299 IU/L,CRP-46.93 mg/L ,Ddimer-5043.96 mg/L. Chest x-ray showed gross cardiomegally. Ultrasonography of abdomen showed dilated IVC and dilatation of hepatic vein and right ventricle with mild PE.Follow up ECHO study of heart showed moderate pericardial effusion with ejection fraction $62 \%$ with good LV function. COVID-19 Antibody test was positive for IgM. Patient symptoms and signs improved with Artesunate therapy for 5 days. This was a case of moderately severe acute COVID-19 infection with CHF.

Case 17 A 50 years old male presented with h/o SOB-2 moths, fever and pain abdomen for 4 days. On examination BP-100/70mmHg, pulse-80/min, PaO2-96 \%(RA). Routine blood test TLC-15.46 $\mathrm{X} 10^{3} / \mu \mathrm{L}, \mathrm{N}-72.5 \quad \mathrm{X} 10^{3} / \mu \mathrm{L} \quad, \mathrm{L}-22.45, \mathrm{E}-0.6 \%, \mathrm{M}-$ $4.5 \%, \mathrm{~B}-0.1 \%, \mathrm{TPC}-17.8 \times 10^{3} / \mu \mathrm{L}$. Baseline serum ferritin was $245 \mathrm{ng} / \mathrm{ml}$, LDH-495 IU/L,D-dimer $<5.0 \mathrm{mg} / \mathrm{L}$. X-ray chest showed Rt. sided mild loculated pleural effusion. CT abdomen showed hepatosplenomegally with minimal ascites. On ECHO of heart there was severe concentric LVH with global hypokinesia, moderate LV dysfunction, mild MR, mild pericardial effusion and mild AR and TR. Treated with IV Artesunate 5 days. Follow up COVID-19 antibody was positive for IgG-1.78 and TAb-3.14 OD ratio. This was a case of moderate severe ongoing symptomatic COVID-19 infection with CHF.

Case 18 A 38 years old male presented with h/o chest pain, palpitation and sweating for 3 days. On examination BP-100/60mmHg, pulse- $88 / \mathrm{min}$, $\mathrm{PaO} 2-98 \%$ (RA) ,RR-20/min. Routine blood test revealed TLC-6.70 X10 $3 / \mu \mathrm{L}, \mathrm{N}-3.6 \times 10^{3} / \mu \mathrm{L}, \mathrm{L}-$ $2.17 \times 10^{3} / \mu \mathrm{L}, \mathrm{TPC}-229 \times 10^{3} / \mu \mathrm{L}, \mathrm{Hb}-15 \mathrm{gm} \%$, ESR-35mm, Na+-138mEq/L, K+-2.8mEq/L. Ferritin-560ng/ml, LDH-500IU/L. lipid profile TC-105mg\%, HDL-24mg\%, TG-70mg\%,LDL$47 \%$, ECG showed acute anterior wall myocardial infarction. Baseline Serum troponin-I was 40,000 $\mathrm{ng} / \mathrm{ml}$ and after 2 days it was 13693ng/ml. Patient responded to IV Artesunate very well. Follow up COVID -19 antibodies IgG was positive 1.70 OD ratio on $10^{\text {th }}$ day after onset of symptoms. This was a case of moderately severe acute COVID-19 infection precipitated AMI.

Case 19 A 33 years old male presented with quadruparesis for 10 days with h/o bout of loose motion of 4-5 episodes 20 days back. On examinations BP-110/70mmHg, pulse-84.min, $\mathrm{PaO} 2-98 \%$ (RA), RR-16/min. On routine blood test TLC-4.91 X10 $3 / \mu \mathrm{L}, \mathrm{N}-60.3 \times 10^{3} / \mu \mathrm{L}, \mathrm{L}-16.9$ X10 ${ }^{3} / \mu \mathrm{L}, \mathrm{E}-2.3 \times 10^{3} / \mu \mathrm{L}, \mathrm{M}-19.5 \times 10^{3} / \mu \mathrm{L}, \mathrm{B}-1 \%$. Serum Na+ was $134 \mathrm{mEq} / \mathrm{l}, \mathrm{K}+4.4 \mathrm{mEq} / \mathrm{L}$, Serum ferritin was $817 \mathrm{ng} / \mathrm{ml}, \mathrm{LDH}-555 \mathrm{IU} / \mathrm{L}, \mathrm{CRP}<5$ $\mathrm{mg} / \mathrm{L}, \quad$ D-dimer-6.1 $\mathrm{mg} / \mathrm{L}$. Treated with IV Artesunate for 5 days. Follow up COVID-19 IgG done only was positive 3.25 OD ratios. Diagnosed to be a case of GBS by nerve conduction study. Patient improved and discharged after able to walk on $14^{\text {th }}$ day. This was a case of moderately severe acute COVID-19 infection presented like GBS.

Case 20 A 56 years old male chronic alcoholic presented with increased distension of abdomen for 10 days and hiccough for 7 days. On examination BP-114/80mmHg, pulse-100/min. On routine blood test TLC-5.17X10 ${ }^{3} / \mu \mathrm{L}, \mathrm{N}-68 \%$, L$9.7 \%, \mathrm{M}-20.8 \%, \quad \mathrm{E}-0.7 \%, \mathrm{~B}-0.8 \%, \mathrm{TPC}-256 \mathrm{X} 10^{3}$ $/ \mu \mathrm{L}$. Serum ferritin was $657 \mathrm{ng} / \mathrm{ml}, \mathrm{LDH}-477 \mathrm{IU} / \mathrm{L}$, D-dimer-11.7 mg/L. USG study showed gross ascites with thickened peritoneum.COVID-19 antibody positive for IgG-5.26 and TAb -3.24 OD ratios. Patient improved with IV Artesunate therapy. Ascites fluid was exudative in nature with lymphocyte predominance and ADA positive This was a case of moderately severe acute COVID-19 infection with TB Peritonitis.

Case 21 A 70 years old male on treatment for DCM \& CHF stable for 1 year, presented with swelling of abdomen and both legs for 15 days and SOB for 10 days. On routine blood test TLC$10.5 \times 10^{3} / \mu \mathrm{L}, \mathrm{N}-85.8 \%, \mathrm{~L}-6.8 \%, \mathrm{M}-7.2 \%, \mathrm{E}-0.2 \%$, TPC-13.79X10 $0^{3} / \mu \mathrm{L}$. serum $\mathrm{Na}+129 \mathrm{mEq} / \mathrm{K}+-$ 3.3mEq/L. Serum ferritin-463ng/ml, LDH-799 IU/L, CRP- $5 \mathrm{mg} / \mathrm{L}$, D-dimer-1.9 mg/L, troponin-I -49 IU/L. X-ray chest showed right sided pleural effusion (exudative).USG abdomen revealed mild ascites, moderate right sided pleural effusion and 
features of CKD. ECHO of heart showed mild MR with severe LV dysfunction with EF26\%.COVID-19 antibody positive for IgG-1.27 and $\mathrm{TAb}-1.33 \mathrm{OD}$ ratios on $20^{\text {th }}$ day from symptom onset. Patient improved with Artesunate therapy and discharged in good conditions. This was a case of moderately severe acute COVID-19 infection precipitated $\mathrm{CHF}$.

Case 22 A 33 year old known CKD and hypertensive female presented with intractable vomiting and altered sensorium and decreased urination for 4 days, with h/o fever for 5 days 1 month back. On examination BP-100/70 mmHg, pulse-80/min, PaO2-94 \%( RA), RR-18/min. On routine blood test TLC- $18.10 X 10^{3} / \mu \mathrm{L}, \mathrm{N}-96.4 \%, \mathrm{~L}-$ $1.5 \%, \mathrm{M}-2.1 \%, \mathrm{TPC}-147 \times 10^{3} / \mu \mathrm{L}, \mathrm{Hb}-8.7 \%$, Na+$104 \mathrm{mEq} / \mathrm{L}, \mathrm{K}+-4.4 \mathrm{mEq} / \mathrm{L}$ and serum ferritin 678ng/ml,CRP-5.0 $\mathrm{mg} / \mathrm{L}$, total CPK-371 $\mu \mathrm{g} / \mathrm{L}$, serum urea- $128 \mathrm{mg} / \mathrm{dl}$, serum creatinine- $7.1 \mathrm{mg} / \mathrm{dl}$. Follow up IgG COVID-19 antibody positive 3.33 OD ratios. After correction of serum sodium and Artesunate therapy, patient conscious improved and was on maintenance dialysis. This was a case of moderately severe ongoing symptomatic COVID-19 with acute AKI on CKD with hyponatraemia.

Case 23 A 57 years old known male hypertensive, COPD and NASH patient presented with loose motion, vomiting, pain abdomen and SOB for 2 days in low conditions. On examinations his BP was $80 / 50 \mathrm{mmHg}$, pulse-90/min, $\mathrm{PaO} 2-70 \%(\mathrm{RA})$, and $92 \%$ with $5 \mathrm{LO}_{2} / \mathrm{min}, \mathrm{RR}-21 / \mathrm{min}$. On routine blood test TLC-13.2 X10 $3 / \mu \mathrm{L}, \mathrm{N}-12.1 \times 10^{3} / \mu \mathrm{L}, \mathrm{L}-$ $1.8 \mathrm{X} 10^{3} / \mu \mathrm{L}$, TPC-12.2 X10 $3 / \mu \mathrm{L}, \mathrm{Hb}-12.2 \mathrm{gm} / \mathrm{dl}$, $\mathrm{Na}+-142 \mathrm{mEq} / \mathrm{L}, \mathrm{K}+-3.1 \mathrm{mEq} / \mathrm{L}$. Serum ferritin was 178.30ng/ml, LDH-583 IU/L, CRP-75 mg/L, Blood urea-81mg/dl ,serum creatinine-2.9mg/dl. Patient treated with IV Artesunate, nasal oxygen therapy and replacement of fluid with potassium and markedly improved within 48 hours. Follow up antibody was positive for $\mathrm{IgG}-17.5$ and $\mathrm{TAb}-$ 2.88 OD ratios. This was a case of severe acute COVID-19 presented with gastrointestinal manifestation.
Case 24 A 65 years old known CKD and COPD female presented with history of fever for 3 days 1 month back and generalized anasarca for 1 month, decreased urination for 10 days and SOB for 7 days with $\mathrm{SpO} 2$ of $89 \%$ (RA), BP-120/70mmHg, pulse-80/min, RR-21/min. Baseline ferritin was 173ng/ml, LDH-402 IU/ml, CRP-32mg/L, Ddimer-0.2 mg/L, blood urea-92mg/dl,creatinine$4.0 \mathrm{mg} / \mathrm{dl}$ chest $\mathrm{x}$-ray showed features of COPD. Patient on nasal oxygen for 7 days and $\mathrm{SpO} 2$ became $98 \%$ (RA) on $7^{\text {th }}$ day. COVID-19 antibody IgG -0.8 and $\mathrm{TAb} 3.77 \mathrm{OD}$ ratios was positive on $10^{\text {th }}$ day from symptom onset. Patient markedly improved and discharged. This was a case of severe ongoing symptomatic COVID-19 case precipitated AKI on CKD.

Case 25 A 68 years old known HTN and CKD female patient presented with SOB and swelling of both leg for 5 days and cough for 2 days with features of CHF. On examination her BP was 160/100mmHg, pulse-78/min, Spo2-82 \%(RA), RR-28/min. On routine blood test TLC$7.15 \times 10^{3} / \mu 1 . \quad \mathrm{N}-74 \%, \mathrm{~L}-13 \%, \mathrm{E}-0.9 \%, \mathrm{~L}-6 \%, \mathrm{TPC}-$ $250,000 / \mu 1, \mathrm{Hb}-8.4 \mathrm{gm} \%, \mathrm{Na}+-133 \mathrm{mEq} / \mathrm{L}, \mathrm{K}+-$ $4.2 \mathrm{mEq} / \mathrm{L}$. Serum ferritin was $270 \mathrm{ng} / \mathrm{ml}$, LDH492 IU/L,CRP-80mg/L,D-dimer-0.04 mg/L, urea$53 \mathrm{mg} / \mathrm{dl}$,creatinine-3.8mg/dl. Chest x-ray showed B/L pleural effusion. USG study showed B/L PE and moderate pericardial effusion. ECHO study of heart showed mild MS, sclerotic aortic valve with calcification, pericardial effusion, Grade I diastolic dysfunction with normal LV systolic function. She was improved with IV Artesunate therapy and COVID-19 specific antibodies on $10^{\text {th }}$ tested positive for IgG-2.57 and TAb-5.52 OD ratios. This was a case of severe acute COVID-19 with CKD with anemia.

Case 26 A 22 years old female presented with fever with chills for 5 days 12 days back and SOB for 6 days and again fever and vomiting for 1 day. On examination her BP was 110/70 $\mathrm{mmHg}$, pulse $96 / \mathrm{min}$, temperature $102^{0} \mathrm{~F}$, RR-22/min, $\mathrm{PaO} 2-96 \%$ (RA). On routine blood test, TLC$16500 / \mu \mathrm{L}, \quad \mathrm{N}-87.2 \%, \quad \mathrm{~L}-8.8 \%, \mathrm{M}-2.5 \%, \mathrm{E}-1.5 \%$,

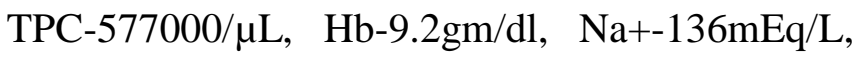


$\mathrm{K}+-3.6 \mathrm{mEq} / \mathrm{L}$. Baseline serum ferritin was 413ng/ml, LDH-299 IU/L,CRP-64 mg/L and after 5 days $32 \mathrm{mg} / \mathrm{L}$, ESR-109mm, D-dimer-130 $\mathrm{mg} / \mathrm{L}$. Fever and vomiting subsided within 48 hours after IV Artesunate therapy and serum ferritin was increased to $719 \mathrm{ng} / \mathrm{ml}$ and $\mathrm{LDH}-708$ IU/L, D-dimer decreased to $1.2 \mathrm{mg} / \mathrm{L}$ on $4^{\text {th }}$ day. COVID-19 antibodies tested on $14^{\text {th }}$ day were positive for TAb-1.66 and IgG-10.25 OD ratios. It was a case of moderately severe acute COVID-19 infection.

Case 27 A 55 years old known male diabetic presented with h/o intermittent fever since 5 months and yellow coloration of urine since 20 days and jaundice for 15 days. On examination his $\mathrm{BP}$ was 110/70mmHg, PR-84/min, RR-15/min, severely pallor, $\mathrm{PaO} 2-90 \%$ ( RA), FBS$>500 \mathrm{mg} / \mathrm{dl}$, managed with insulin, pioglitazone, Metformin and Teneligliptin. On routine blood test TLC-2.29X10 $1 / \mu \mathrm{L}$, TPC- $148 \times 10^{3} / \mu \mathrm{L}, \mathrm{Hb}-$ $3.1 \mathrm{gm} / \mathrm{dl}$ with biocytopenia. Blood biomarker ferritin was >1000ng/ml, LDH-370 IU/L, Ddimer-82 mg/L, Blood urea-196mg/dl,creatinine$9.0 \mathrm{mg} / \mathrm{dl}$. USG study showed hepatosplenomegally. Fever subsided after 3 days of Artesunate therapy and Hemoglobin level remained stable at $6 \mathrm{gm} / \mathrm{dl}$ after three blood transfusions. After 5 days of Artesunate therapy repeat serum ferritin was $>1000 \mathrm{ng} / \mathrm{ml}$, LDH-301 IU/L, D-dimer-7.1 mg/L. COVID-19 antibody test was done after 7 days of hospitalization tested positive for TAb-6.16 and IgG was > 20 OD ratios. It was a case of severe ongoing symptomatic COVID-19 or a long COVID-19 syndrome.

Case 28 A 72 years old known T2DM, CAD male presented with cough with expectoration, chest pain and SOB for 3 days. On examination his BP was $100 / 80 \mathrm{mmHg}$, pulse rate $130 / \mathrm{min}, \mathrm{RR}$ 42/min, $\mathrm{PaO} 2$ was $88 \%(\mathrm{RA})$. On routine blood test TLC $-20.7 \times 10^{3} / \mu \mathrm{L}, \mathrm{N}-74 \%$, L-17\%,E-9\%, $\mathrm{Na}+126 \mathrm{mEq} / \mathrm{L}, \mathrm{K}+-4.0 \mathrm{mEq} / \mathrm{L}$. Blood biomarkerferritin was 260ng/ml, LDH-291 IU/L, D-dimer$0.1 \mathrm{mg} / \mathrm{L}$, Troponin-I-45.9ng/dl, chest $\mathrm{x}$-ray showed GGO of right middle and lower lobe of lung. HRCT of thorax showed patchy consolidation of right middle and multifocal GGO in bilateral upper lobe.2D ECHO of heart showed RWMA in LAD, LCX territory with mild MR with severe LV dysfunction. Patient treated with IV Artesunate and his oxygen saturation increased to $>94 \%$ (RA) on $3^{\text {rd }}$ day with marked improvement with $\mathrm{PaO} 2>98 \%$ (RA) on $5^{\text {th }}$ day. COVID-19 antibody test for IgM was positive 4.33 and $\mathrm{IgG}-7.54$ OD ratios. This was a case of severe acute COVID-19 infection.

Case 29 A 53 years old male of known bronchial asthma on maintenance Formonide inhalation 200 $\mu \mathrm{g}$ twice daily presented with intermittent fever and loss of appetite for 15 days, general weakness for 12 days, cough with expectoration and SOB for 5 days with $\mathrm{PaO}_{2} 93 \%$ (RA). On routine blood test TLC-9.18X10 $/ \mu \mathrm{L}, \mathrm{N}-81 \%, \mathrm{~L}-11.8 \%, \mathrm{M}-6.4 \%$, E- $0.7 \%, \quad \mathrm{Hb}-13.4 \mathrm{~g} / \mathrm{dl} . \mathrm{TPC}-302 \mathrm{X} 10^{3} / \mu \mathrm{L}$. Serum $\mathrm{K}+-3.2 \mathrm{mmol} / \mathrm{L}, \mathrm{Na}+-130 \mathrm{mmol} / \mathrm{L}$. Serum LDH was $698 \mathrm{IU} / \mathrm{ml}, \mathrm{CRP}-84 \mathrm{mg} / \mathrm{L}$, D-dimer was $<0.01 \mathrm{mg} / \mathrm{Land}$ serum ferritin was $445 \mathrm{ng} / \mathrm{ml}$. Repeated serum LDH on $4^{\text {th }}$ day was $514 \mathrm{IU} / \mathrm{L}$, CRP-65.7 mg/L, ferritin-993ng/ml, D-dimer- 0.1 $\mathrm{mg} / \mathrm{L}$. HRCT of thorax done on $1^{\text {st }}$ day of admission was characteristic of COVID-19 infection with CT score of 12/25 (moderate severity). His fever subsided after one day of Artesunate therapy and oxygen saturation on $2^{\text {nd }}$ days $98 \%$ (RA) and discharged on $5^{\text {th }}$ day. Follow up COVID-19 antibody test positive for $\mathrm{IgG}$ positive >20 index (CLIA) and TAb- 7.01 OD ratios (ELISA) on $20^{\text {th }}$ day. This was a case of moderately severe acute COVID-19 infection.

Case 30 A 42 years old female presented with intermittent fever with chills for 7 days and altered sensorium with irritability (GCS-8/15) from 6th day and primary referral report with ICT pf. Malaria positive .O/E BP-110/70 mmHg, PR100/min, RR-20/min,Temp-100.1 $1^{0}$ F ,SpO2 94\%(RA), Pallor present. Baseline TLC$3.8 X 103 / \mu \mathrm{L}, \quad \mathrm{N}-44 \%, \mathrm{~L}-38.4 \%, \mathrm{E}-0.3, \mathrm{M}-16.5 \%$, $\mathrm{Hb}-6.0 \mathrm{gm} / \mathrm{dl}$, TPC-91X103/ $\mu \mathrm{L}$, Urea-53mg/dl, Creatinine-1.3gm/dl, CRP-28.25 mg/L, D-dimer$5.65 \mathrm{mg} / \mathrm{L}$, Ferritin 466ng/ml.MP-QBC and ICT for malaria was negative .Chest $\mathrm{x}$-ray showed $\mathrm{B} / \mathrm{L}$ 
peripheral lung infiltrates with GGO. She was treated with IV Artesunate for 5 days and markedly improved within $48 \mathrm{hrs}$ and repeated biomarkers tests on $5^{\text {th }}$ day showed TLC$5.72 \times 10^{3} / \mu \mathrm{L}, \mathrm{N}-89 \%, \mathrm{~L}-4.6 \%, \mathrm{M}-6.4 \%, \mathrm{E}-0.0 \%$, $\mathrm{Hb}-6.2 \mathrm{gm} \%$, TPC-284x103/ $\mathrm{L}$, Creatinine$1.0 \mathrm{mg} / \mathrm{dl}$, Urea-31mg/dl, CRP-5.2 mg/L, D-dimer1.93 mg/L, serum Ferritin-360ng/ml. SARS-CoV2 antibody (ELISA)- IgM was positive (1.50 OD ratio) on 14th day of illness and HRCT thoraxshowed CORAD-4(severity Index-3/25) . This was a case of cerebral malaria with moderately severe acute COVID-19 infection.

Case 31 A 19 old male presented with intermittent fever with chills and rigor for 21 days and profound weakness for 7 days. On examination there was severe pallor, BP-80/60mmHg with vasopressor, $\mathrm{PaO} 2-98 \%$ (RA), PR-136/min, RR$30 / \mathrm{min}$.On routine blood test -TLC$11.23 \times 10^{3} / \mu \mathrm{L}, \quad \mathrm{N}-6.73 \times 10^{3} / \mu \mathrm{L}, \mathrm{L}-3.53 \times 10^{3} / \mu \mathrm{L}$, $\mathrm{N}-59.9 \%, 1-31 \%, \mathrm{M}-7.6 \%$, E-0.6\%, B- $0.6 \% . \mathrm{Hb}-$ 3.7gm\%,CV-71fl,MCH-23.2pg.Dengue Ns1 and IgM-ve, Scrubtyphus IgM and IgG - ve, MPQBC- ve, but ICT + ve for pf. Malaria, CRP-45.7 $\mathrm{mg} / \mathrm{L}$,Ferritin-852ng/ml,D-dimer-0.13 $\mathrm{mg} / \mathrm{L}$, ESR-78mm. Follow up antibodies for COVID-19 positive for IgM-1.32 OD ratio. Patient improved with IV Artesunate and two blood transfusions. This was a case of pf. Malaria with moderately severe acute COVID-19 infection responded both to IV Artesunate.

\section{Discussion}

\section{1: RT-PCR Test for COVID-19 Infection}

The diagnostic performance of gold standard RTPCR test depends on many factors such as the sample types, different stages of infection, the skill of sample collection and the quality and consistency of the PCR assays being used. ${ }^{2}$ These problems lead to a noteworthy delay of early diagnosis, following management and propose serious challenges. ${ }^{3}$ In a study RT-PCR test done in 213 COVID-19 patients by Yang et $\mathrm{al}^{4}{ }^{4}$ collected 205 throat, 490 nasal swab and 142 sputum samples from day 1 to 7 days of illness, of whom $11 \%$ sputum ,27\% nasal ,40\% throat swabs were falsely negative. In another study by Zhao et $\mathrm{al}^{\mathbf{5}}$ in 107 hospitalized patients with acute symptoms and chest-x-ray typical of COVID-19 infection, with at least one sample positive for SARS-CoV-2 antibodies seroconversion were in 93\% and RT-PCR test was positive from day 1 to 7 was in $67 \%$. In a systemic review of five studies among 957 patients by Steven et al, ${ }^{6}$ false negative results reported from 2-94\%. Thus, there are frequent false negative RT-PCR results and the clinicians should assume a negative result as 'false negative' in a person with typical symptoms and signs.

In-vitro analysis suggest that RT-PCR test is highly specific and sensitive for SARS-Cov-2 viral RNA detection in nasopharyngeal swab, but in clinical setting of 87 Chinese patients RT-PCR nasopharyngeal swab test sensitivity and specificity was $78.3 \%$ and $98.8 \%$ respectively and sensitivity was $62.5 \%$ in mild cases. In another study of 205 confirmed COVID-19 patients with 398 pharyngeal swab, only 126 (32\%) were positive, but with BALF test RT-PCR was positive in $93 \%$ and with sputum $72 \%$ (Wang et al). ${ }^{7}$ In a study of 51 patients with HRCT characteristic of COVID-19 in 50 (98\%) initial RT-PCR was positive only in $30(71 \%)$. Thus, RT-PCR test has high specificity but the sensitivity is between $63-78 \%$. For patients with moderately severe cases, HRCT imaging of the chest may be more sensitivity than RT-PCR. Thus, negative RT-PCR test does not rule out the disease. $^{8}$

\section{2: Symptoms of COVID-19 Infection}

Fever, cough and fatigue are the most common symptoms, whereas nasal congestion, runny and diarrhoea are less common. It has been noted that some of COVID-19 patients had mild atypical symptoms initially, even with severe and critical illness. ' Severe cases might rapidly progress to acute respiratory distress syndrome (ARDS), septic shock and metabolic acidosis and bleeding disorders. ${ }^{10}$ Fever and symptoms screening misses many coronavirus cases ${ }^{\mathbf{1 1}}$ New study adds to 
COVID-19 Symptoms are weakness, poor blood sugar control and gastrointestinal complaints as warning signs of COVID-19. Among 12000 Patients 57.1\% attended New York City hospital complained of weakness, falls or altered mental status, $55.5 \%$ had GIT problem and aged $\geq 65$ years persons mostly complain atypical symptoms such as diarrhoea, fatigue, and weakness. ${ }^{\mathbf{1 2}}$

\section{3: Definitions of COVID-19 Infection according to Duration of Illness}

Guideline has been developed jointly by NICE, SIGN and RCGP and recommended the used of the following clinical definitions for the initial illness and long COVID-19: Acute COVID-19: Signs and symptoms of COVID-19 lasted for up to 4 weeks. Ongoing symptomatic COVID-19: Signs and symptoms continue from 4 to 12 weeks. Post-COVID-19 syndrome: Signs and symptoms that develop during or after an infection consistent with COVID-19 continue for more than 12 weeks and are not explained by an alternative diagnosis. Long COVID: The term 'long COVID' is commonly used to describe signs and symptoms those continue or develop after acute COVID-19. It includes both ongoing symptomatic COVID-19 (from 4 to 12 weeks) and post-COVID-19 syndrome ( $\geq 12$ weeks or more). ${ }^{\mathbf{1 3}}$

\section{4: Diagnostic and Prognostic Blood Biomarkers Criteria of COVID-19 Infection}

In a study of 203 patients with typical clinical features of fever, cough and/or dyspnoea with chest $\mathrm{x}$-ray and HRCT of chest findings, RT-PCR tests were positive in $46 \%$ patients and negative in $54 \%$ patients. As COVID-19 infection is an inflammatory disease. Diagnostic criteria for suspected Clinical COVID-19 were done with blood inflammatory biomarkers to determine sensitivity and specificity by analyzing ROC curve, calculating the AUC and the cutoff value with a specificity of $89 \%$ was considered for following blood biomarkers to met the diagnosis of clinical COVID-19 infection: If Serum ferritin levels $>125 \%$ (1.25 times) of URL $300 \mu \mathrm{g} / \mathrm{L}-(\mathrm{M})$ and $200 \mu \mathrm{g} / \mathrm{L}(\mathrm{F})$ had sensitivity of $66 \%$ (56.8$76.4)$ and specificity of $85 \%$ (77.3-91.4) was the most accurate biomarker. Eosinophils counts $\leq 0.02 \times 10^{9} / \mathrm{L}$ with sensitivity of $64 \%$ (54.4-74.5) and specificity of $79 \%$ (71.1-86.9). Serum LDH levels $>125 \%$ of URL-(290 IU/L(F) and 325 U/L for $(\mathrm{M})$ with sensitivity of $62 \%(51.1-71.5)$ and specificity of $77 \%$ (67-83.8), hsCRP level $>80 \mathrm{mg} / \mathrm{L}$ with sensitivity of $46 \%(36.4-57.4)$ and specificity of $81 \%$ (72.1- 87.7).Lymphocyte count $\leq 1000$ cells $/ \mu \mathrm{L}$ with sensitivity of $43 \%$ (32.4-33.2) and specificity of $81 \%(72.1-$ 87.7).Serum D-dimer levels $>1.2 \mathrm{mg} / \mathrm{L}$ with sensitivity of $33 \%(23.6-43.4)$ and specificity of $79 \%$ (71.1-86.9). Over all, if $\geq$ one criteria present in clinically suspected COVID-19 patients then diagnosis of clinical COVID-19 was made with sensitivity of $91 \%$ (83.9-96.3) and specificity was $47 \%$ (38.1-57.5). Thus, these criteria can be used as diagnostic tools to differentiate patients with and without COVID-19 and among suspected clinical COVID-19 with RT-PCR negative patients as complementary along with other tests. ${ }^{\mathbf{1 4}}$ A recent systematic review highlighted the most important laboratory tests alterations were increased values of CRP (95.8\%), LDH (76.9\%), ferritin $(60.7 \%)$, D-dimer $(54.8 \%)$, neutrophil to lymphocyte ratio [NLR] $(50.1 \%)$ and aspartate aminotransferase [AST] (48.9\%), as well as lymphocytopenia (49.8\%) within the first $24 \mathrm{hr}$ at ED visit. ${ }^{15}$ If some or all of these parameters raised and there was lymphocytopenia or eosinopenia suggested diagnosis in RT-PCR negative cases and considered as severe disease. ${ }^{16}{ }^{\prime 17}$ Lymphocyte count $<1000$ cells $/ \mu \mathrm{L}$ correlate with increased severity and development of AKI during hospitalization in $68 \%$ patients with $>7$ days ICU stay and increased mortality. ${ }^{18}$ Lactate dehydrogenase (LDH) is an enzyme involved in conversion of lactate to pyruvate and interconversion of NADH and NAD+. It is present in almost all body cells increased following tissue breakdown and decreased oxygenation, considered as an inflammatory marker. Severe infections may cause cytokine-mediated tissue damage and $\mathrm{LDH}$ release. $\mathrm{LDH}$ enzymes are five separate isoenzymes and LDH-3 is present in 
pneumocytes. C-reactive protein (CRP) is a reliable marker of acute inflammation, synthesized in the liver regulated by the cytokine IL-6 and IL1. LDH and CRP could be useful marker for the early identification of COVID-19 patients. $^{\mathbf{1 9} 20}$ Elevated LDH levels were associated with a $~ 6-$ fold increase in odds of developing severe disease and a $\sim 16$-fold increase in odds of mortality. ${ }^{21}{ }^{22}$ These findings could be related to the cytokine storm in patients with severe to critical disease. ${ }^{\mathbf{2 3}}$ Trends on serial laboratory measurements with progressive lymphopenia, thrombocytopenia and elevated CRP, ferritin, LDH, increased liver enzymes, decreased renal function, and coagulation derangements were more common among critically ill patient. ${ }^{24}$ Studies demonstrated that routine blood and biomarkers tests had detection rates similar to those of RT-PCR with a positive predictive value and negative predictive value of $83.3 \%$ and $90.6 \%$ respectively. ${ }^{25}$

\subsection{HRCT Thorax and RT-PCR Sensitivity for Diagnosis of COVID-19 Infection}

In a series of 81 patients HRCT of thorax detected COVID-19 infection greater than RT-PCR testing (98\% versus $71 \%$ ), suggest screening of HRCT chest of patients with typical clinical features particularly when RT-PCR is negative. ${ }^{26}$ In a study of chest HRCT of 1014 patients, RT-PCR was positive in 59\% and HRCT was positive in $88 \%$ and HRCT sensitivity was $97 \% .{ }^{27}$ Combination of RT-PCR and chest CT had higher sensitivity (91.9\%) and CT alone have sensitivity of $66.7 \%$ versus RT-PCR alone $78.2 \%$ for detection of COVID-19 infection. ${ }^{28}$

\section{6: Testing of COVID-19 Specific Antibodies}

The cumulative seroconversion curve showed that the rate for total antibody (TAb) and IgM reached $100 \%$ around 1-month after onset of disease. The seroconversions were sequentially appeared for $\mathrm{TAb}, \mathrm{IgM}$ and then IgG. The median time to TAb, IgM and IgG seroconversion were 11, 12 and 14day respectively. Overall, the seroconversion of $\mathrm{TAb}$ was significantly quicker than that of $\operatorname{IgM}$ and IgG. In the early phase of illness within 7 day s, RT-PCR had the highest sensitivity of $66.7 \%$, whereas the antibody positivity rate of $38.3 \%$. However, the sensitivity of TAb overtook that of RNA test since day 8 and reached over $90 \%$ across day 12 after onset. In serum samples from patients during day 8-14, the sensitivities of $\mathrm{TAb}$ was $(89.6 \%), \operatorname{IgM}(73.3 \%)$ and $\operatorname{IgG}(54.1 \%)$ were higher than the RT-PCR test (54.0\%). Among patient's samples collected during day 15-39, sensitivities of $\mathrm{TAb}, \operatorname{IgM}$ and $\mathrm{IgG}$ were $100.0 \%$, $94.3 \%$ and $79.8 \%$, respectively; in contrast RTPCR test positive in $45.5 \%$. Respiratory tract samples collected among patients during day 1-3, $4-7,8-14$ and $15-39$, there were $28.6 \%, 53.6 \%$ $98.2 \%$, and $100 \%$ respectively had detectable $\mathrm{TAb}$. Detection of $\mathrm{TAb}$ was more sensitive than IgM and IgG for detecting SARS-CoV-2 infection in early stages and similar to IgM. ${ }^{\mathbf{2 9}}$

\section{7: Scientific Rationale of IV Bolus Artesunate Therapy for COVID-19 Infection}

Ruiyuan Cao, et al in their study found $\mathrm{EC}_{50}(50 \%$ effective concentration) of Artesunate was $12.8 \pm 5.30 \mu \mathrm{M}$ and Dihydroartemisinin (DHA) had $13.31 \pm 1.24 \mu \mathrm{M}$ against SARS-CoV-2 in-vitro, indicating Artesunate as a potential countermeasure against COVID-19 infection. Artesunate could inhibit SARS-CoV-2 replication in a dose-dependent manner, might function at the post-entry stage and SARS-CoV-2 inhibited by Artesunate and DHA. ${ }^{30}$ Bae JY et al, in their study in Vero cells, shown that Artesunate inhibited SARS-CoV-2 replication with $\mathrm{IC}_{50}$ of $53.06 \mu \mathrm{M}, \mathrm{CC}_{50}$ of $>100 \mu \mathrm{M}$. Interestingly, in Calu-3 cells, (which are derived from human airway epithelial cells was more representative of susceptible cells in actual human airway infection), Artesunate inhibitory effect had $\mathrm{IC}_{50}$ of $1.76 \mu \mathrm{M}, \mathrm{CC}_{50}>100 \mu \mathrm{M}$, better than in Vero cells and reduced viral replication in a dose-dependent manner. ${ }^{31}$ After $120 \mathrm{mg}$ of IV AS produce Cmax of $11,343 \mathrm{ng} / \mathrm{ml}(42 \mu \mathrm{M})$ with $\mathrm{t}^{1} / 2$ of $0.05 \mathrm{hrs}$ and Cmax of DHA was $2,646 \mathrm{ng} / \mathrm{ml}$ with $\mathrm{t}^{1} / 2$ of 0.67 hrs (total 13,987ng/ml), ${ }^{32}$ which were greater than $\mathrm{EC}_{50}$ of Artesunate and DHA against SARS-CoV2. In another study $120 \mathrm{mg}$ IV bolus Artesunate produced Cmax of $29.5 \mu \mathrm{M}$ with elimination $\mathrm{t}^{1} / 2$ 
of 2.7 min and Cmax for DHA was $9.3 \mu \mathrm{M}$ with $\mathrm{t}$ $1 / 2$ of $40 \mathrm{~min}$ and $100 \mathrm{mg}$ oral AS produce DHA Cmax of $2.6 \mu \mathrm{M}, \mathrm{t}^{1} / 2$ of $39 \mathrm{~min}^{33}$ Gilmore $\mathrm{K}$ et al in Vero E6 cells study: Artesunate $\mathrm{EC}_{50}$ had 7$12 \mu \mathrm{g} / \mathrm{ml}$ or $(0.7-1.2 \mu \mathrm{M})$ was more potent than Artemisinin. Cmax of Artesunate exceeding $\mathrm{EC}_{50}$ can be achievable clinically in plasma and tissue concentrations of $15 \mu \mathrm{g} / \mathrm{ml}$ and the typical doses of 2 - $2.4 \mathrm{mg} / \mathrm{kg}$ IV bolus produces Cmax of AS between 19.4 and $29.7 \mu \mathrm{g} / \mathrm{ml}$.In animal studies tissue concentrations including lung, kidney, intestine, and spleen were several-fold higher than plasma concentrations. ${ }^{34}$ Artemisinins administration leads to autoinduction of hepatic drug metabolism and reduces its own bioavailability. The plasma concentrations of same daily dose of AS were $1 / 3$ rd less on day 3 onwards than on day $1 .^{35}$ The PK variability following 120mg IV AS with high Cmax occurs with first exposure time and the Cmax variability ranges from 735-1890ng/ml(AS+DHA) and this variability was 25 fold among different clinical trials. There is large inter-individual PK/PD variability and such low drug concentrations in some patients may explain treatment failure. Thus, low dose regimen of AS to be avoided. ${ }^{36}$ High dose IV bolus Artesunate preferred to achieve higher free peak plasma levels of Artesunate and DHA and have higher bioavailability to enter the human cells in comparison to Artemether and Arteether. ${ }^{37}$ Patients with severe COVID-19 may have many critical and variable conditions and comorbidities with variable severity scores that may determine the drug's PK/PD characteristics and prognosis. The current dose of $120 \mathrm{mg}$ IV AS produce variable Cmax ranging from 735$1890 \mathrm{ng} / \mathrm{ml}$ with greater inter individual variability have lower Cmax. The $4-8 \mathrm{mg} / \mathrm{kg}$ loading dose is safe and in phase I-II study IV AS $4-8 \mathrm{mg} / \mathrm{kg}$ loading doses were extremely well tolerated in humane volunteers and malaria patients. ${ }^{38}$ Artesunate Cmax is more important than AUC in producing improved efficacy and IV bolus Artesunate provide sufficient high Cmax in patients and avoid inter-individual variability in
PK/PD. Artesunate IV bolus injection following $4 \mathrm{mg} / \mathrm{kg}$ produce Cmax of $36,100 \mathrm{ng} / \mathrm{ml}$ and following $8 \mathrm{mg} / \mathrm{kg}$ Cmax of $89,340 \mathrm{ng} / \mathrm{ml} .{ }^{39}$ Optimal doses and dose intervals for Artesunate and DHA have not been determined.Therefore,in the absence of well controlled dose-ranging studies and valid pharmacodynamic relationships, widely used empirical regimens remain unchallenged. $^{33}$

1.9: Coronavirus replication cycle is around $8-10$ hrs. ${ }^{40,41}$ Artesunate has Cmax dependent effects and IV bolus infusion (in 2-10 minutes) initiated with $4-8 \mathrm{mg} / \mathrm{kg}$ at interval of $8-10 \mathrm{hr}$ or even $12 \mathrm{hly}$ can achieve higher plasma Cmax for the first exposure given for a short course of $\geq 3$ to 5 days to cover 9 to 15 replication cycles in early stage of robust viral replication can prevent disease progression as well as avoided auto-induction of its own metabolism and low Cmax. Besides its antiviral effects, Artesunate have antiinflammatory, immunomodulatory, antioxidant, anticytokine, anti-fibrotic and organs protective effects in hypoxia and can be beneficial even in later stages or in the cytokine storm to reduce morbidity and mortality. ${ }^{\mathbf{4 2}}$

\subsection{0: Artesunate effectiveness in clinical trial} of COVID-19 patients: In a prospective study of 43 cases of COVID-19 patients divided into routine treatment group $(\mathrm{n}=25)$ and Artesunate group $60 \mathrm{mg}$ IV twice daily along with routine treatment for 10 days $(\mathrm{n}=18)$. Among Artesunate group, time for significant improvement of symptoms was (days: $3.33 \pm 1.91$ vs. $4.84 \pm 2.19$ ), RT-PCR negative conversion time was (days: $4.72 \pm 2.16$ vs. $6.68 \pm 3.76$ ), lung lesion absorption starting time (days: $5.39 \pm 2.36$ vs. $7.48 \pm 3.78$ ), lung lesion absorption $>70 \%$ time (days: $14.11 \pm 4.16$ vs. 17.04 \pm 4.42 ) and length of hospital stay (days: $16.56 \pm 3.71$ vs. $18.04 \pm 3.97$ ) were significantly shorter, than those in routine treatment group with fewer adverse reactions. ${ }^{43}$

\section{Conclusions}

COVID-19 infection is not localized to respiratory tract but is a "multisystem disease" and affects 
any organs of the body or in combinations. There have been variable clinical presentations of COVID-19 infection in different co-morbidities. Rapid antigen and RT-PCR test have frequent false negative results. Routine blood, inflammatory and coagulation biomarkers along with imaging studies and COVID-19 specific antibodies tests are very sensitive indicators of diagnosis of COVID-19 infection. HRCT of thorax can detect COVID-19 infection better than RT-PCR test. Combinations of these tests have high sensitivity and specificity for the diagnosis than RT-PCR test alone. Artesunate have antiSARS-CoV-2 effects in vitro studies, having very short half-life and dose dependent effects with excellent safety profiles during treatment of patients. High dose IV bolus Artesunate produces high Cmax and exceeds many times $\mathrm{EC}_{50}$ of Artesunate and its metabolite DHA against SARSCoV-2. Thus, high dose IV bolus Artesunate producing high $\mathrm{Cmax}$ to be given for 3-5 days to cover 10 to 15 replication cycle of (8-10hour) coronavirus in the early stage of robust viral multiplication to prevent progression of disease, complications and deaths. Beside its antimalarial and anti-viral effect it have anti-inflammatory, anti-cytokine, immunomodulatory, anti-oxidant, anti-fibrotic, hypoxic organ protective effects, may effective even in later stages of the disease. High dose IV bolus Artesunate therapy for 5 days appears to be very effective with excellent safety profile with faster resolution of symptoms, improves oxygen saturation rapidly in hypoxic patients and decreased morbidity and mortality among COVID-19 infected patients. However, large multicenter placebo control, double blind, dose ranges, frequency and duration of therapy studies are required among RT-PCR/ RAT positive COVID-19 patients for its recommendation.

\section{Conflicts of Interest: Nil}

\section{References}

1. Samprathi M, Jayashree M.Biomarkers in COVID-19: An up-To Date Review. Front. Pediatr. https://doi.org./10.3389/fped.2020.607647.

2. Zou LR, Ruan F, Huang MX, et al. SARSCoV-2 viral load in upper respiratory specimens of infected patients. NEJM. 2020; published online Feb 19. https://doi.org/ 10. 1056/ NEJM c2001737.

3. Huang CL, Wang YM, Li XW, et al. Clinical features of patients infected with 2019 novel coronavirus in Wuhan, China. Lancet 2020. Published online Jan 24. https://doi.org/10.1016/ S01406736(20)30183-5.

4. Yang $\mathrm{Y}$, Yang $\mathrm{M}$, Shen $\mathrm{C}$ et al. Evaluating the accuracy of different respiratory specimens in the laboratory diagnosis and monitoring the viral shedding of 2019 nCov infection. Feb 17, 2020.

https://www.medrxiv.org/content/10.1101/ 2020.02.11.20021493v2.

5. Zhao J, Young Q, Wang H et al. Antibody response to SARS-CoV-2 in patients of novel coronavirus disease 2019. Cli Infect Dis.2020 March 28 (Eupub ahead of print).

6. Steven Woloshin, Neeraj Patel, Aaron S, Kesselheim. False Negative Test for SARS-CoV-2 Infection- Challenges and Implications. NEJM. August 6, 2020; e38 (1-3) down loaded on Sept 23, 2020.

7. Wang $\mathrm{M}, \mathrm{Wu} \mathrm{Q}, \mathrm{Xu} \mathrm{WZ}$, et al. Clinical diagnosis of 8274 samples with 2019novel coronavirus in Wuhan. MedRxiv 2020; published online Feb 18. DOI: 10.1101/2020.02.12.20022327.

8. Tong Zitek. The Appropriate use of testing for COVID-19.Western Journal of Emergency Medicine. May .2020; 21(3):470-472.

9. Huang CL, Wang YM, Li XW, et al. Clinical features of patients infected with 
2019 novel coronavirus in Wuhan, China. Lancet. 2020. Published online Jan 24.https://doi.org/ 10.1016/ S01406736(20)30183-5.

10. Chen NS, Zhou M, Dong X, et al. Epidemiological and clinical characteristics of 99 cases of 2019 novel coronavirus pneumonia in Wuhan, China: a descriptive study. Lancet 2020. Published online Jan 29. https://doi.org/10.1016/ S01406736(20)30211-7.

11. Fever, symptoms screening misses many coronavirus cases. Mindscape. Nov 12.2020 .

12. New study Adds to COVID-19 symptoms list. Medscape. Nov.9, 2020. https: //bitly3pcqjnp. American Journal of Emergency Medicine. Online. Nov 7, 2020.

13. COVID-19 rapid guideline: managing the long-term effects of COVID-19. NICE guideline Published: 18 December 2020. www.nice.org.uk/ng188.

14. JD Santotoribo, DN-Jurado, ELBalsalobre. Evaluation of Routine blood Tests for Diagnosis of Suspected Coronavirus Disease 2019.Clinical Lab.9/2020 June 8; 66:xxxx. Doi.10.7754/Clin.Lab.2020.200522.

15. L García de Guadiana-Romualdo et al. Characteristics and laboratory findings on admission to the emergency department among 2873 hospitalized patients with COVID-19: the impact of adjusted laboratory tests in multicenter studies. A multicenter study in Spain (BIOCOVIDSpain study). Scandinavian Journal of Clinical and Laboratory Investigation. https:// doi.org/ 10.1080/ 00365513. 2021.1881997.

16. TP Velaran, CG Mayer. Mild versus severe COVID-19: Laboratory Markers. Int J Infect Dis.95 (2020):304-
307.https://doi.org/10.1016/J.IJID.2020.04 .061 .

17. B Sun, Y Feng, X Mo, P Zheng, Q Wang, $\mathrm{P}$ Li, P Peng et al. Kinetics of SARS-CoV2 specific $\operatorname{IgM}$ and $\operatorname{IgG}$ responses in COVID-19 patients. Emerging Microbes \& Infections.2020, VOL. 9: 941-948. https:// doi.org.10.1080/22221751.2020.1762515.

18. J Wagner, A Dupent, S Larsal, B Cash, A Farooq. Absolute lymphocyte count is prognostic marker in COVID-19: A retrospective cohort review. Int $\mathrm{J}$ Lab Hematol.2020; 001-5.Wileyonline library.com/journal/ijih.

19. E. Poggiali, D Zaino, $P$ Immovilli, L Rovero, G Losi, et al. Lactate dehydrogenase and C-reactive protein as predictors of respiratory failure in CoVID19 patients.Clinica Chimica Acta 509 (2020) 135-138.

20. Mei-ying Wu, L Yao, Yi Wang, Xin-yun Zhu, Xia-fang Wang, Pei-jun Tang and Cheng Chen. Clinical evaluation of potential usefulness of serum lactate dehydrogenase (LDH) in 2019 novel coronavirus (COVID-19) Pneumonia. Respiratory Research (2020) 21:171. https://doi.org/10.1186/s12931-02001427-8.

21. BM Henry, G Aggarwal, J Wong, S Benoit, J Vikse, M Plebani, G Lippi. Lactate dehydrogenase levels predict coronavirus disease 2019 (COVID-19) severity and mortality: A pooled analysis. American Journal of Emergency Medicine 38 (2020) 1722 1726.https://doi.org/10.1016/j.ajem.2020.0 5.073 .

22. Bermejo-Martin JF, Almansa R, Menendez $\mathrm{R}$, et al. Lymphopenia community acquired pneumonia as signature of severe COVID-19 infection. J Infect. 2020; 80(5):e23-e24. 
23. Wang J, Jiang M, Chen X, et al. Cytokine storm and leukocyte changes in mild versus severe SARS-CoV-2 infection: review of 3939 COVID-19 patients in China and emerging pathogenesis and therapy concepts. J Leukoc Biol. 2020; 108(1):17-41.

24. S Kiss, N Gede, P Hegyi, D Németh, M Földi et al. Early changes in laboratory parameters are predictors of mortality and ICU admission in patients with COVID- 19: a systematic review and meta- analysis.Medical Microbiology and Immunology (2021) 210:33-47. https:// doi.org /10.1007/s00430-020-00696-w.

25. Y Tjendra, Abdulaziz F. Al Mana, Andrea P. Espejo, Y Akgun, Nicolas C. Millan et al. Predicting Disease Severity and Outcome in COVID-19 Patients. A Review of Multiple Biomarkers. Prognostic Biomarkers in Patients with COVID-19.Arch Pathol Lab Med. 2020; 144:1465-1474; doi:10.5858/arpa.20200471-SA.

26. Fang Y, Zheng H, Xie J, Lin M, Ying I, Pang P, Ji W. Sensitivity of chest CT for COVID-19: Comparison to RT-PCR. Radiology.Feb19: 2020:200432. https:// pub.rsna.org/ doi. 10.1148 / radiol.2020.200432.

27. AI T, Yang Z, Hou H, Zhan C,Lv W, Tao Q, Sun Z, Xia L. Correlation of chest CT and RT-PCR testing in coronavirus Disease 2019(COVID-19) in China. A report of 1014 cases.Radiology.2020, Feb 26:200642.https://pubs.rsna.org/doi.10.114 8/radiol.2020200642.

28. X Ren, Yan Liu, H Chen, Ei Liu, ZW Guo, Y Xhang et al. Application and optimization of RT-PCR in Diagnosis of SARS-CoV-2 infection. MedRxiv:https://www.medRxiv.org/conte nt/doi.10.1101/2020.02.25.20027755v2.

29. Zhao J, Yuong Q, Wang $\mathrm{H}$ et al. Antibody response to SARS-CoV-2 in patients of novel coronavirus disease 2019.Clin Infect Dis .2020 March 28 (Eupub ahead of preprint).

30. Ruiyuan Cao, Hengrui Hu, Yufeng Li, Xi Wang, Mingyue $\mathrm{Xu}$, Jia Liu. et al. AntiSARS-CoV-2 Potential of Artemisinins InVitro. ACS Infect Dis. July 31, 2020. https://dx.doi.org/10.1021/acsinfecdis.0c0 0522.

31. Joon-Yong Bae, Gee Eun Lee, Heedo Park, Juyoung Cho, Yung-Eui Kim, JooYeon Lee, Chung Ju, Won-Ki Kim, Jin Il Kim, Man-Seong Park. Pyronaridine and artesunate are potential antiviral drugs against COVID-19 and influenza. bioRxiv preprint doi: https://doi.org/10.1101/2020.07.28.225102 ; this version posted July 28, 2020.

32. Ilett KF, Batty KT. Powell S. M Binh, T Q, Thu 1., Phuong HL, Hung NC, Davis TM. The pharmacokinetic properties of intramuscular Artesunate and rectal Dihydroartemisinin in uncomplicated falciparum malaria. Br. J. Clin. Pharmacol.2002; 53, 23-30.

33. Kevin T. Batty, Le Thi Anh Thu,Timothy M. E. Davis, Kenneth F. Ilett,Truong Xuan Mai,Nguyen Canh Hung,Nguyen Phuc Tien,Shane M. Powell, Huynh Van Thien,Tran Quang Binh \& Nguyen Van Kim. A pharmacokinetic and pharmacodynamic study of intravenous vs oral artesunate in uncomplicated falciparum malaria. Br J Clin Pharmacol 1998; 45: 123-129.

34. Gilmore K, Y Zhou Y, Ramirez S, Long V. Pham, Fahnøe U, et al, In vitro efficacy of Artemisinin-based treatments against SARS-CoV-2, bioRxiv preprint doi: https:// doi.org./10.1101/2020.10.05.326637. October 52020.

35. Gordi T, Xie R, Huong NV, Huong DX, Karlsson MO, Ashton M. A semi physiological pharmacokinetic model for 
artemisinin in healthy subjects incorporating autoinduction of metabolism and saturable first pass hepatic extraction.Br J Clin Pharmacol.2005; 59:189-98.

36. Karbwang J , Na-Bangchang K, Thanavibut A, Molunto P. Plasma concentrations of artemether and its major plasma metabolite Dihydroartemisinin following a 5 day regimen of oral artemether in patients with uncomplicated falciparum malaria. Ann Trop Med Parsit. 1998; 92:31-36.

37. Li Q, Xie LH, Haeberle A, Zhang J, Weina $P$. The evaluation of radiolabel Artesunate in tissue distribution in rats and protein binding in human. Am $\mathrm{J}$ Trop Med Hyg. 1006; 75:817-826.

38. Li Q, Milhous WK, Weina PJ. Artemisinin in malaria therapy. Overseas press (India) Pvt. Ltd. First Edn.2003.p-10, 82, 84, 98.

39. Qisui Li,Lowis R Catilena ,Kevin J Leary,George A,Saviolakis R,Scott Miller ,Victor Melendez,,Peter J Weina. Pharmacokinetic profiles of Artesunate after single intraveinous dose at 0.5.,1,2,4 and $8 \mathrm{mg} / \mathrm{kg}$ in healthy volunteers; A phase I study. Am J tROP Med Hyg.81(4); 2009;pp-615621.doi.10.4269/ajtmh.2009.09.0150.

40. YM Bar-On, A Flamholz, R Phillips, R Milo. Science Forum. SARS-CoV-2 (COVID-19) by the numbers. eLife.2020; 9:e57309.

DOI https://doi.org/10.7554/eLife.57309.p- 115.

41. Fehr AR, Periman S, (2015), Coronavirus: an overview of their replication and pathogenesis. Method Mol Biol.1282; 123.

42. Pradhan B, Nanda BC, Pradhan G. JMSCR.08:10; October 2020.p-215-225.
43. Lin Y,Wu F,Xie Z,Song X,Zhu X,Zhu Q, Wei J,Tan S,Liang L.Ging B L. Clinical study of Artesunate in the treatment of coronavirus disease 2019.Europe PMC. 01 Apr 2020, 32(4):417-420. DOI: 10.3760/cma.j.cn121430-2020031200412. PMID: 3252734. 